\title{
Geology and Mineral Resources of
}

the Kuluncak-Sofular Area (Malatya $\mathrm{K} 39-\mathrm{a}_{1}$ and $\mathrm{K} 39-\mathrm{a}_{2}$ Quadrangles), Turkey

GEOLOGICAL SURVEY BULLETIN 1429

Prepared in cooperation with the Maden Tetkik ve Arama Enstitüsü under the auspices of the Government of Turkey and the Agency for International Development U.S. Department of State 



\section{Geology and Mineral Resources of the Kuluncak-Sofular Area (Malatya $\mathrm{K}-39 \mathrm{a}_{1}$ and K39-a $\mathrm{a}_{2}$ Quadrangles), Turkey}

By GERHARD W. LEO, ERCAN ÖNDER, MEHMET KILIÇ, and MURAT AVCI
G E O L O G I C A L
S U R V E Y
B U L L E T I N
1429

Prepared in cooperation with the Maden Tetkik ve Arama Enstitüsü under the auspices of the Government of Turkey and the A gency for International Development U.S. Department of State

Faulted and deformed Cretaceous to Holocene sedimentary rocks and associated alkaline and calc-alkalic volcanic rocks rest on an Alpine-type ultramafic basement. Minor iron and base-metal mineralization exists 


\title{
UNITED STATES DEPARTMENT OF THE INTERIOR
}

CECIL. D. ANDRUS, Secretary

\author{
GEOLOGICAL SURVEY
}

H. William Menard Director

\footnotetext{
Library of Congress Cataloging in Publication Data

Leo, Gerhard W

Geology and mineral resources of the Kuluncak-Sofular area (Malatya K39-a

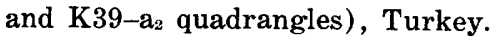

(Geological Survey bulletin ; 1429)

Bibliography: p.

Supt. of Docs. no.: I 19.3:1429

1. Geology-Turkey-Kuluncak region. 2. Mines and mineral resources-TurkeyKuluncak region. I. Ankara. Maden Tetkik ve Arama Enstitüsü. II. Title. III. Series: U.S. Geological Survey. Bulletin ; 1429.

QE75.B9 no. 1429 [QE316] 557.3’08s [555.61] 76-608363
}

For sale by Superintendent of Documents, U.S. Government Printing Office Washington, D.C. 20402

Stock Number 024-001-03102-7 


\section{CONTENTS}

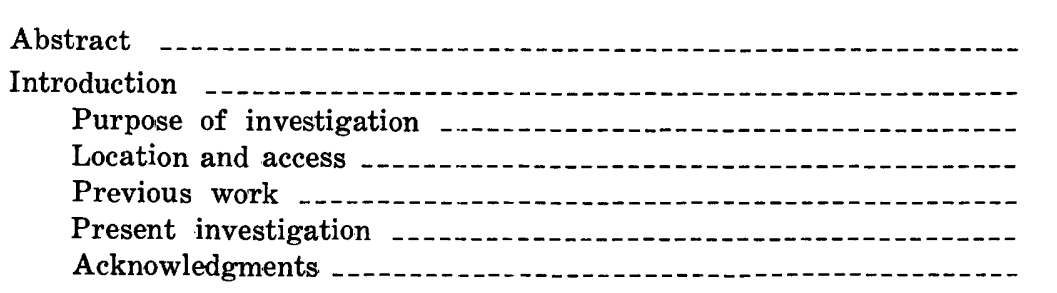

General geology _-_.

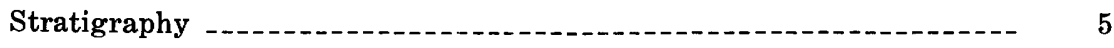

Stratigraphic nomenclature _._. 5

Cretaceous _-

Tohma Group _. 5

Tökler Formation _. 6

Sofular Formation _....... 7

Age of the Tohma Group _... 9

Limestone of Çakşan Tepe

Limestone of Karapinar Dere _... 10

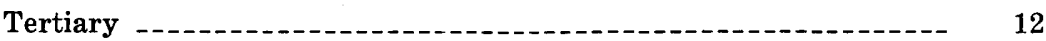

Limestone of Çaltepe _-_._. 12

Sedimentary sequence of Inceciğin Dere _..._._._._._. 13

Limestone of Yapalaklı Tepe _...... 17

Dolomite of Özbek _._.

Tertiary or Quaternary _-_._. 19

Upper Tertiary or Quaternary conglomerate and travertine -- 19

Quaternary _._. 19

Terrace gravel _...

Landslides _._.

Alluvium _.......

Intrusive and volcanic rocks _._. 20

Pre-Cretaceous or Cretaceous

Serpentinite-gabbro complex

Cretaceous _- 29

Alkalic diabase -

Cretaceous and Tertiary _._. 31

Trachyte and trachyandesite

Alkalic syenite of Avliya Dere

Age of trachytic rocks and syenite

Middle to upper Miocene volcanic sequence -

Compositional and age relationships of the igneous rocks _... $\quad 37$ 
Structure

Faults

Yunnuk-Düşüksöğüt fault system

Faults in the Körmustafalar area

Faults in the Çaltepe-Ziyaretçalı Tepe area

Folds

Economic geology

Iron prospects

Lead, zinc, and copper prospects

Chromite mines and prospects 50

References cited

\section{ILLUSTRATIONS}

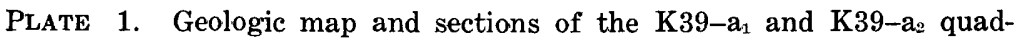
rangles, Turkey _........... In pocket

2. Map showing aeromagnetic and ground magnetic studies in the Kuluncak-Sofular area, Turkey _............... In pocket

FigURE 1. F-M-Alk diagram of igneous rocks of the Kuluncak-Sofular area

Page

2. Or-Ab-An diagram of igneous rocks of the Kuluncak-Sofular area

3. Contoured silica-differentiation index diagram

\section{TABLES}

TABLE 1. Chemical analyses of igneous rocks in the Kuluncak-Sofular area

2. Lead, zinc, and copper in trachyte and ultramafic rocks, Kuluncak area 


\title{
GEOLOGY AND MINERAL RESOURCES OF THE KULUNCAK-SOFULAR AREA (MALATYA K39-a ${ }_{1}$ AND K39-a QUADRANGLES), TURKEY
}

\author{
By Gerhard W. Leo, ${ }^{1}$ Ercan ÖNder, ${ }^{2}$ \\ Mehmet Kiliç, ${ }^{2}$ and Murat Avgi ${ }^{2}$
}

\begin{abstract}
The Kuluncak-Sofular area, constituting most of the Malatya K39-a and K39- $\mathbf{a}_{2}$ quadrangles, is roughly halfway between Malatya and Sivas in eastcentral Turkey. Geologic mapping and evaluation of mineral resources in the area were done in 1969 as part of a joint program between the Maden Tetkik ve Arama Enstitüsü of Turkey (MTA) and the U.S. Geological Survey (USGS).

The area is underlain by a variety of sedimentary, plutonic, and volcanic rocks, most of which are between middle Cretaceous and late Tertiary age. A complex of serpentinite and gabbro of unknown age of emplacement was exposed as a depositional basement about middle Cretaceous time. Upon this was deposited an Upper Cretaceous sequence of conglomerate, tuffaceous graywacke, silicic tuff, and subordinate rudistid-bearing limestone, dolomite, mudstone, and siltstone (Tohma Group), and a unit of massive, fractured cherty limestone (limestone of Karapinar Dere). The Tohma Group was intruded by plugs and sills of alkalic diabase, followed by thick flows of trachyte-trachyandesite and associated dikes, plugs, and stocks. An isolated, possibly related stock of alkalic syenite intrudes the limestone of Karapinar Dere.

Next in the geologic column are a Nummulites-rich, bedded, and contorted limestone of probable early Eocene age (limestone of Caltepe) and a middle to upper Eocene sequence of conglomerate, sandstone, and limestone (sedimentary sequence of İnceciğin Dere). The sedimentary sequence is overlain by a middle to upper Miocene sequence of mafic to intermediate volcanic rocks. These partly overlie and partly cut freshwater limestone (limestone of Yapalakl Tepe) and are overlain by thin-bedded dolomite (dolomite of Özbek). A variety of partly consolidated, upper Tertiary and Quaternary sediments cap all other rock units.

The dominant structural trend in the area is west-northwest, but there are many local variations. A major northwest-trending fault zone that has many subsidiary faults appears to be related to intermittent uplift and
\end{abstract}

1 U. S. Geological Survey.

Maden Tetkik ve Arama Enstitïsü, Ankara, Turkey 
tectonic mobilization of serpentinite that produced contortion and fracturing of overlying rocks. West-northwest-trending faults of apparently large displacement cut serpentinite and conglomerate of the Tohma Group in the southwestern part of the area.

Known mineral deposits are mostly small and unimportant, although some have been mined for several decades. Local accumulations of magnetite are found in silica-carbonate-weathering crusts overlying serpentinite, which is a peculiar, not fully explained phenomenon. Serpentinite itself contains small scattered chromite deposits. Lead-zinc deposits have formed locally at fractured contacts between trachyte dikes and serpentinite. Geochemical patterns suggest that additional lead-zinc deposits may be present at shallow depth, and further geochemical prospecting is recommended.

\section{INTRODUCTION}

\section{PURPOSE OF INVESTIGATION}

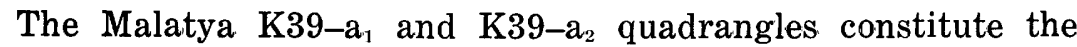
central part of an east-trending belt of six 71/2-minute quadrangles in central Turkey chosen for detailed investigation under a joint project by the Maden Tetkik ve Arama Enstitüsü of Turkey (MTA) and the U.S. Geological Survey (USGS), sponsored by the Government of Turkey and the Agency for International Development, U.S. Department of State. The area (index, pl. 1) was chosen for study on the basis of known iron and base-metal deposits. The presently producing Karakuz iron mine (Jacobson and Boğaz, 1972) is just outside the eastern boundary of the area discussed herein. The Karakuz deposit is on a major east-trending fault zone, which is also the locus of the Deveci mine $20 \mathrm{~km}$ farther east. Hence, similar deposits could reasonably be expected on any westerly extension of this zone. The fault zone, moreover, lines up approximately with aeromagnetic anomalies near Düşüksögüut Tepe (Düşüksöğüt Hill) in the area of the present report. Also, small lead-zinc deposits, including the recently shutdown mine of Rasih ve Ihsan Maden Ltd., Sti., on Salloğlanın Dere (Sallığlanın Creek), were known in the report area.

\section{LOCATION AND ACCESS}

The Kuluncak-Sofular area is $30 \mathrm{~km}$ northwest of Hekimhan, a town of about 3,000 inhabitants along the graveled MalatyaSivas road about $70 \mathrm{~km}$ northwest of Malatya (index, pl. 1). From Hekimhan, a dirt road, impassable between November and late April, leads to the large village of Kuluncak. A stabilized road runs from Kuluncak along Tohma Suyu (Tohma River) to Sofular village and thence northward out of the mapped area. 
This road and some of subsidiary, mainly dry-weather tracks provide adequate access by jeep.

Kuluncak is also accessible from Darende on the MalatyaKayseri highway, but the Darende-Kuluncak road is in poor condition and is passable only in dry weather and by jeep.

\section{PREVIOUS WORK}

The Kuluncak area has been studied periodically for more than 30 years by geologists associated with MTA. Among the earliest studies was that of Blumenthal (see section "Unpublished reports"), who made a regional reconnaissance study of the geology and speculated on the origin of the iron deposits. Early appraisals of the mineral potential of the area between Kuluncak and the Devici mine (index, pl. 1) were made by Müller (see section "Unpublished reports") and Kovenko (see section "Unpublished reports"). K. E. Izdar (see section "Unpublished reports") made a reconnaissance study of the region between the villages of Kuluncak, Sofular, and Iğdelidere, including most of quadrangles $\mathrm{K} 39-\mathrm{a}_{1}$ and $\mathrm{K} 39-\mathrm{a}_{2}$, and a more thorough study of the HekimhanHasançelebi area to the east (Izdar, 1963). The area of the present report was remapped by Taner Ayan (see section "Unpublished reports") and Sitki Ilker (see section "Unpublished reports") of MTA. The latter data unfortunately were unavailable when the project was being planned, and the extent of the work already done in the area was not known until mapping was nearly completed.

\section{PRESENT INVESTIGATION}

Geologic mapping was done between April and October 1969; topographic bases and aerial photographs were used. Streamsediment samples for determination of base-metal concentration were collected in selected areas, and ground-magnetometer surveys were conducted. About 225 thin sections were studied. Chemical analyses of geologically significant rock specimens were made in the USGS laboratories; some analyses were also made in the MTA laboratories.

The junior authors participated in field mapping and sample collection; in addition, Kiliç measured a section of the Sofular Formation, and önder aided with geochemical determinations. Erdal Altunlu of MTA assisted in the field for 3 months. The geological interpretations and preparation of the report were done by the senior author, who assumes responsibility for any errors. 


\section{ACKNOWLEDGMENTS}

Thanks are due Sadullah Bilgin, manager of Bilfer Şirketi, Ltd., and his staff for providing living arrangements and other courtesies during the summer of 1969 . We are also grateful to Taner Subaşı, mining engineer for Rasih ve Ihsan Ltd., for his assistance in facilitating study of the lead-zinc mine on Salloğlanın Dere. Asil Tin, MTA geologist, provided valuable help in translation of reports and in drafting.

\section{GENERAL GEOLOGY}

The map area is in the central Anatolian Plateau. According to a traditional subdivision of major tectonic units in Turkey (Ketin, $1959,1966)$, the region is within the Taurid belt, which also includes the Taurus Mountains along the Mediterranean Coast of Turkey. The Taurid belt consists principally of unmetamorphosed sedimentary and volcanic rocks that range in age from Ordovician through Miocene; the east-central part of the belt is marked by large ultramafic intrusions (Brinkmann, 1968). The broad regional relationships in this part of the Anatolia were described by Baykal and Erentöz (1966), and shown in the 1:500,000-scale geologic map (Sivas $6^{\circ}$ sheet).

According to Rigo de Righi and Cortesini (1946), the southern part of the Taurid belt is a mobile zone emplaced from the north during several episodes of large-scale gravity sliding between Late Cretaceous and Pliocene time. In the Kuluncak-Sofular area, which is well north of the mobile zone (Rigo de Righi and Cortesini, 1964, fig. 2), no evidence of gravity-slide tectonics was observed.

Within the mapped area (pl. 1), the principal rock units range in age from middle Cretaceous to late Tertiary. The principal units are: serpentinite and associated rocks; an Upper Cretaceous sequence of conglomerate, graywacke, tuff, and diabase; massive to bedded limestones of Late Cretaceous through probable Eocene age; a sequence of Eocene conglomerate, sandstone, and associated freshwater limestone; and mafic to intermediate volcanic rocks of middle Tertiary to late Tertiary age.

Rocks underlying the region are moderately folded and locally much broken by faults. Most older rocks are strongly deformed, and even some Quaternary deposits are uplifted and tilted. The regional structural trend in the Kuluncak-Sofular area is westnorthwest. About $12 \mathrm{~km}$ west of Sofular, the trend changes abruptly to northeast by way of a major structural bend across 
a north-trending fault zone; the northeast trend is expressed both by folds and faults (Barosh and others, 1972).

\section{STRATIGRAPHY}

\section{STRATIGRAPHIC NOMENCLATURE}

Two types of stratigraphic names are used in this report for the rock units mapped. Formal terms (Sofular Formation, Tohma Group) are proposed when stratigraphic data are sufficient to justify formal assignment; usage of terms follows the guidelines of the Turkish Stratigraphic Names Committee (written commun., 1968). Where data are insufficient for formal stratigraphic designation, informal but geographically based names (for example, limestone of Karapinar Dere) are introduced. Such informal names may be changed to formal ones (for example, Karapinar Dere Limestone or Karapınar Dere Formation) when sufficient information becomes available.

\section{GRETACEOUS}

TOHMA GROUP

The name Tohma Group is proposed here and by Barosh and others (1972) for a sequence of Upper Cretaceous sedimentary and volcanic rocks that occupies much of the central part of

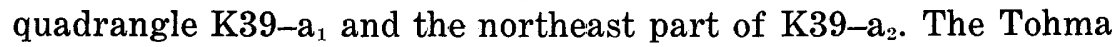
Group is named after Tohma Suyu, which flows through the main outcrop area.

The Tohma Group is divided into two formations. The lower one, the Tökler Formation, consists dominantly of conglomerate, but contains minor siltstone, sandstone, and biohermal limestone; the upper one, the Sofular Formation, consists mainly of tuffaceous graywacke, but contains welded tuff, and some minor amounts of siltstone and dolomite. The Tohma Group is intruded by sills and plugs of alkalic diabase concentrated in the lower part of the Sofular and the upper part of the Tökler. Mafic flows, mostly pillow basalts, at the eastern margin of the area are assigned to the Sofular Formation.

The Tohma Group strikes generally northwest and dips moderately to steeply northeast. It rests unconformably on the serpentine-gabbro complex and is overlain by trachyte, which may be partly intrusive and partly extrusive. The thickness of the group is estimated to be $4,000-5,000 \mathrm{~m}$.

A sedimentary-volcanic sequence near Hekimhan-Hasançelebi, east of the map area, which is apparently equivalent to the 
Tohma Group, has been divided into three parts by Izdar (1963, p. 8-11), as follows: Klastische Sedimente der Oberkreidetransgression, Rudistenriffkalke and Flyschartige Oberkreide. Approximately the same stratigraphic sequence in the same area has more recently been designated Upper Cretaceous volcanic-sedimentary sequence by Jacobson and others (1972). The entire sequence was included in the informally named Hekimhan Formation of Ayan (see section "Unpublished reports").

\section{TÖKLER FORMATION}

The Tökler Formation, named after the village of Tökler on the north bank of Tohma Suyu in quadrangle K38- $\mathrm{b}_{2}$, was formally proposed and described by Barosh and others (1972). The formation is well exposed over a large area south of Tohma Suyu in quadrangle K39- $a_{1}$. Near the western edge of the quadrangle, the formation is repeated by several faults and has an exposed width of nearly $6 \mathrm{~km}$ across strike. Its true thickness within the mapped area appears to be about $1,500 \mathrm{~m}$ and certainly does not exceed $2,000 \mathrm{~m}$.

The Tökler Formation consists dominantly of reddish- to brownish-purple cobble conglomerate. Most of the cobbles are gabbro and serpentine; peridotite, jasper, siltstone, and dolomite constitute the remainder. The conglomerate is typically well bedded, well sorted, and tightly to poorly cemented. The bedding is better developed and more distinct toward the top of the section, where prominent flatirons of steeply northeast-dipping beds are locally exposed. Lower in the section, the bedding is less well developed and can be discerned only locally.

The conglomerate rests unconformably on the serpentine-gabbro complex. The contact is well exposed $1 \mathrm{~km}$ southwest of Sofular on the northwest side of Hamalçayı Dere, where it is sharp and dips $50^{\circ}-70^{\circ} \mathrm{NNE}$. Near the contact, the conglomerate is poorly sorted; boulders are as much as $1 \mathrm{~m}$ across and consist of serpentinite, gabbro, and subordinate jasper and mafic volcanic rocks. Above the contact there is a noticeable decrease in serpentinite and jasper clasts, the proportion of gabbro increases, the degree of sorting improves, and the average diameter of the constituent cobbles decreases gradually. The Tökler conglomerate evidently formed as a basal conglomerate on a serpentine-gabbro surface; the jasper cobbles show that a siliceous weathering crust had already developed at least locally. Elsewhere, the serpentinegabbro complex remained exposed during the deposition of the Tökler Formation and continued to provide an abundant source 
for conglomerate in which gabbro cobbles, because of their greater hardness and resistance, were preferentially preserved.

Approximately $500 \mathrm{~m}$ below the top of the Tökler Formation, the relative amount of conglomerate begins to diminish, and the unit lenses out; in contrast, the amount of sandstone (tuffaceous graywacke) and thin-bedded, flaggy dolomite containing small angular clasts of quartz and feldspar increases. Mainly within the upper few hundred meters, but also lower in the section, are reeflike lenses of limestone ("Rudistenriffkalke" of Izdar, 1963, p. 9) as much as $50 \mathrm{~m}$ thick and $500 \mathrm{~m}$ long, but commonly smaller. Several such lenses are exposed between Sofular and Kizilburun Sirt (Kizilburun ridge) in the western part of K39$a_{1}$. The limestone lenses are composed largely of rudistids but also contain other fossils of Late Cretaceous age (see section "Age of the Tohma Group"). The uppermost of these lenses marks an discontinuous layer designated as the top of the Tökler Formation; except for this layer, the contact between the Tökler and Sofular Formations is gradational. Where the limestone lenses are absent, as in the area southwest of Nurluca Tepe between Sofular and Bicir, the contact has been located somewhat arbitrarily (pl. 1) to fit the structural relationships, but has also been placed below the lowest outcrops of a greenish, slightly welded tuff that is typical of the Sofular.

The Tökler Formation apparently corresponds to the Klastische Sedimente der Oberkreidetransgression and the Rudistenriffalke described by Izdar (1963, p. 8-10) in the Hekimhan-Hasançelebi area. It may also correlate with a volcanic conglomerate described

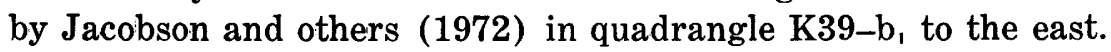

SOFULAR FORMATION

The name Sofular Formation is hereby proposed for a sequence, consisting mainly of tuffaceous graywacke, slightly welded tuff, and thin-bedded siltstone and dolomite, that concordantly overlies the Tökler Formation along a gradational contact. In quadrangle K39- $\mathrm{a}_{1}$, the Sofular Formation crops out in a northwesttrending belt mainly north of Tohma Suyu. Exposures of the Sofular Formation extend to about $2.5 \mathrm{~km}$ west of Tökler village in quadrangle $\mathrm{K} 38=\mathrm{b}_{2}$ (Barosh and others, 1972) and eastward to the boundary between quadrangle K39- $\mathrm{a}_{1}$ and K39- $\mathrm{a}_{2}$ about 1 $\mathrm{km}$ north of Karabaşınkale Tepe and $2 \mathrm{~km}$ northeast of Yünlüce village. Plugs and sills of diabase are associated with the Tohma Group. Pillow lavas interbedded with tuff and agglomerate east of Yanıkharman Tepe and Ciğdemli Tepe (pl. 1, eastern edge of 
$\mathrm{K} 39-\mathrm{a}_{2}$ ), which continue into $\mathrm{K} 39-\mathrm{b}_{1}$ and $\mathrm{K} 39-\mathrm{b}_{2}$ (Jacobson and others, 1972), are probably equivalent to the Sofular Formation, although specific correlation has not been made. Large tracts of the mafic rocks in the $\mathrm{K} 39-\mathrm{b}_{1}$ and $\mathrm{K} 39-\mathrm{b}_{2}$ quadrangles between the Karakuz mine and Çulhalı village are metasomatized (Jacobson and others, 1972; see also section on "Alkalic diabase" and eastern edge of pl. 1, this report).

A generalized section of the Sofular Formation (section 1, western edge of pl. 1), measured northward (hence, bottom to top) from the west side of Kizllburun Sirt and passing about 100 $\mathrm{m}$ west of the summit of Yelekyüce Tepe, is as follows:

\title{
Generalized section of Sofular Formation
}

Meters

$0-24$

24-27

27-30

$30-44$

$44-74$

$74-90$

90-95

95-116

116-202

202-228

228-349

$349-424$

$424-464$

464-742

[Measured by M. Kılıç]

\author{
Description
}

Tuffaceous graywacke, gray-green, massively bedded; consists of angular to subangular grains of quartz, intermediate to silicic volcanic rocks, and clastic chloritic material, all in a carbonate matrix. Locally abundant small pebbles include mafic, ultramafic (serpentinite), and volcanic rocks and jasper. Graywacke is gradationally interbedded with siltstone and also with finely crystalline, platy, greenish-gray to gray-brown dolomite containing scattered angular grains of quartz and feldspar.

Tuff, apple-green to brownish-purple, slightly welded; typically shows eutaxitic texture imparted by flattened fragments of rock and altered volcanic glass; breaks along curved planes generally parallel to this layering, or may be dense, with irregular hackly fracture and less marked eutaxitic texture; consists of potassic feldspar, sodic plagioclase, and rock fragments, mostly trachyte, in an isotropic to low-birefringent groundmass showing indistinct remnants of shards and pumice fragments.

Diabase, fine- to medium-grained, more or less altered; shows evidence of deuteric enrichment in alkalies; locally contains one or several of the following minerals: potassic feldspar, feldspathoid, green amphibole, or biotite.

Graywacke (as above).

Diabase (as above).

Graywacke grading to siltstone.

Welded tuff.

Diabase.

Graywacke interbedded with siltstone and dolomite.

Interbedded welded tuff and graywacke.

Welded tuff.

Interbedded welded tuff and graywacke grading to siltstone; some dolomite beds.

Graywacke, sandy dolomite (?), and siltstone.

Mainly welded tuff; local beds of graywacke, siltstone, and dolomite.

Contact with trachyte-trachyandesite. 
Similar rock types were found within the Sofular Formation along the line of cross section $A-A^{\prime}$ (pl. 1), although exposures there were insufficient to justify measuring a section.

The top of the Sofular Formation is drawn at the contact with overlying trachyte-trachyandesite. The contact is poorly exposed, but the outcrop pattern indicates that it is generally subhorizontal; thus, the trachytic rocks probably are mainly flows, but elsewhere there is evidence that they are intrusive in part. The composition of the welded tuff of the Sofular Formation (table 1, analyses 15-17) is fairly similar to that of the overlying trachyandesite (table 1, and analyses 12 and 13), which suggests that the tuff represents an early phase of the trachytic volcanic episode.

On Zorbehan Dağ (Zorbehan Mountain) north of Hekimhan, the "Flyschartige Oberkreide" described by Izdar (Izdar, 1963, p. 10), which can be correlated with the Sofular Formation, is overlain by yellow dolomitic limestone and light-colored, massive cavernous limestone of Maestrichtian age (Izdar, 1963, p. 11). Correlative limestone was not found in the Kuluncak-Sofular area.

The maximum exposed thickness of the Sofular Formation, measured approximately along section $A-A^{\prime}$, is estimated at about $1,200 \mathrm{~m}$; however, in view of the unconformably overlying trachyte-trachyandesite, the true thickness may be greater.

The composite section of the Tohma Group in this area thus is indicative of eugeosynclinal deposition into a very shallow basin. The thick uniform conglomerate section of the Tökler Formation reflects deposition in a prolonged littoral environment during rapid uplift and erosion of mafic-ultramafic rocks. Deposition of the generally finer grained clastic sediments and interbedded dolomite of the Sofular Formation may signal a change to epineritic conditions, in which water depths were less than about $40 \mathrm{~m}$, or may indicate that the source of the sediments was at a greater distance. Even at this stage, however, cyclic submergence and emergence is indicated by the continuous sequence of interbedded sediments and subaerial tuff. The lack of crossbedding and other features indicative of mechanical agitation and the presence of wood fragments in the Sofular suggest that the depositional basin was relatively restricted (lagoonal) rather than the margin of an open sea.

\section{AGE OF THE TOHMA GROUP}

The following fossils have been identified by Norman F. Sohl, U.S. Geological Survey, from the Tohma Group: 


\begin{tabular}{|c|c|}
\hline $\begin{array}{c}\text { Location } \\
\quad \text { pl. } 1\end{array}$ & Description \\
\hline 1,2 & Paracaprinula sp. \\
\hline 1,2 & Sauvagesia sp. \\
\hline 2 & $\begin{array}{l}\text { Hippuritid rudist } \\
\quad \text { (Pseudovaccinites? }\end{array}$ \\
\hline 3 & $\begin{array}{l}\text { Campanile cf. C. mor } \\
\text { Douville. } \\
\text { Trochachtaeon sp. } \\
\text { Pseudovaccinites sp. }\end{array}$ \\
\hline $1,2,4$ & $\begin{array}{l}\text { Undetermined corals, } \\
\text { rudist, radiolitid. }\end{array}$ \\
\hline 5 & Plagioptychus sp. \\
\hline
\end{tabular}

Remarks

Locality 1: Limestone reef in Tökler Formation; position unknown.

Locality 2: Limestone reefs, Tökler Formation; within $600 \mathrm{~m}$ of top.

Graywacke and siltstone, Tökler Formation; within $300 \mathrm{~m}$ of top.

Limestone reef, top of Tökler Formation.

Mudstone of the Sofular Formation, near bottom.

This assemblage indicates a general range from Campanian to Maestrichtian (Late Cretaceous) (N. F. Sohl, written commun., 1970). A similar age range is reported for corresponding strata ("Klastische Sedimente der Oberkreidetransgression," "Rudistenriffkalke," and "Flyschartige Oberkreide") by Izdar (1963, p. 8-11), Ayan (see section "Unpublished reports"), and Ilker (see section "Uupublished reports"); however, although most of the species reported by the last two authors are different from the above.

\section{LIMESTONE OF ÇAKŞAN TEPE}

This unit, named by Barosh and others (1972), crops out in the extreme southwest corner of K39-a $\mathrm{a}_{1}$ (pl. 1). The limestone is light gray-brown and somewhat granular; in the few exposures seen, it is thinly and evenly bedded. No fossils were seen in outcrops, but abundant rudistid fragments were observed in the soil; hence, the limestone of Çakşan Tepe appears to be Late Cretaceous in age.

No stratigraphic contacts are exposed. In $\mathrm{K} 39-\mathrm{a}_{1}$, the limestone is faulted against serpentine. Farther west, it overlies the Tohma Group with probable fault contact (Barosh and others, 1972), but it is not in contact with the Tohma Group in the area of this report.

\section{LIMESTONE OF KARAPINAR DERE}

The informal name, limestone of Karapinar Dere, is applied to a unit of uncertain age exposed in a broad northwest-trending belt, about $10 \mathrm{~km}$ long and $5 \mathrm{~km}$ wide, northeast of the Yunnuk- 
Düşüksöğüt fault system. The limestone is named after Karapınar Dere, which has cut a deep gorge into the exposures in the northern part of the outcrop area. Because of the general lack of bedding or marker horizons, the thickness of the limestone is unknown.

The limestone of Karapınar Dere is a dense, massive, light-gray to black rock that typically forms low rounded hills. It is locally bedded, as at Kaloğluçalı Tepe and southeast of Oğlakkıran Tepe, but bedding is not typical. The limestone commonly is fractured and contains fracture fillings of white calcite; pods and irregular veins of brown to red-brown chert are locally abundant. Near serpentine contacts, the amount of chert increases and the limestone is locally brecciated. Brecciation and replacement by chert are particularly pronounced in the exposures of Zülfükaroğluçalı Tepe and near Yunnuk Dere to the south. Bedded limestone in this general area is highly contorted.

The grain size of the limestone varies from fine to coarse, typically over short distances and in an irregular manner. Coarsegrain size is associated with fracture fillings and with fractured limestone generally, but is not specifically related to serpentinite contacts. Coarse, recrystallized limestone, however, constitutes the contact aureole of the alkalic syenite body of Avliya Dere; this is the only clear-cut case of contact metamorphism in the study area.

The age and stratigraphic relationships of the limestone of Karapinar Dere are only approximately known as the unit is devoid of fossils and its upper and lower contacts are unconformable. The lower contact with serpentinite may have been depositional originally, but shows evidence of faulting or cold intrusion of serpentinite. The limestone is overlain by the sedimentary sequence of Incecigin Dere of Eocene age. It is also intruded by the alkalic syenite of Avliya Dere, which has been dated at about 65 m.y., and hence falls at the Cretaceous-Paleocene boundary (Leo and others, 1974). Hence, the limestone of Karapinar Dere cannot be younger than Late Cretaceous. The sparse evidence suggests that it is contemporaneous with, or slightly younger than, the Tohma Group.

Ayan (see section "Unpublished reports") regarded the limestone of Karapınar Dere as Jurassic or Early Cretaceous in age on the basis of correlation with fossil-bearing limestone east and northeast of the present map area, which he called Etyemez Dağ limestone. This correlation could not be confirmed in the present study. Further evidence for the older age of the Etyemez Dağ 1 limestone was the assumption of Ayan (see section "Unpublished 
reports") and others that the limestone was intruded by the Cretaceous serpentinite-gabbro complex. As shown elsewhere in this report, this interpretation is open to doubt. Furthermore, in the mapped area, the limestone of Karapinar Dere has not been observed to underlie the Tohma Group.

On the basis of available information, the limestone of Karapinar Dere is regarded here as Late Cretaceous in age.

\section{TERTIARY}

LIMESTONE OF ÇALTEPE

Fractured, contorted Nummulites-bearing limestone crops out along the northern boundary of quadrangle K39- $\mathrm{a}_{2}$ and extends eastward beyond the mapped area. The limestone underlies the highest peaks in the mapped area (Çaltepe, Ziyaretçalı Tepe, Lalo Tepe). The unit is informally named after one of these peaks. Exposures of the limestone are almost completely bare.

Two distinct varieties were noted in the limestone of Chaltepe:

1. Gray, massive, fine- to coarse-grained, generally unbedded limestone, highly fractured and locally brecciated, containing abundant pods and lenses of chert; locally silicified and iron stained; locally abundant Nummulites, but unfossiliferous in many places. Unfossiliferous beds resemble limestone of Karapmar Dere.

2. Yellow-brown to gray-brown or red-brown limestone with massive to platy bedding and an aphanitic to sugary texture; local thin beds of sedimentary breccia; fracturing and silicification absent; unfossiliferous to highly nummulitic.

These two limestone varieties show an irregular outcrop pattern, but in several places, as in Haldeim Dere and on the south flank of Ziyaretçali Tepe, they are interbedded and locally gradational. Apparently the two limestones represent a facies change within a single unit. This is odd in view of the very different character of the two varieties, notably the fracturing and silicification of the gray limestone and the complete absence of these features in the yellow-brown variety; nevertheless, no other conclusion appears justified.

Attitudes measured mainly in the platy yellow-brown limestone show a predominance of roughly east strikes and north dips, but there are many variations, and local tight folding is evident.

An ellipsoidal area in gray limestone about 400 by $300 \mathrm{~m}$ in extent in the saddle between Çaltepe and Ziyaretçali Tepe (area marked "si" on pl. 1) is silicified and iron stained; this may be 
related to faulting along two parallel west-northwest-trending fractures on either side of this locality. Silicification and iron stain are also evident along the southern partly faulted contact within $1 \mathrm{~km}$ east-northeast of Konaktepe village.

The exact stratigraphic position of the limestone of Çaltepe is unknown as it is bounded by faults or covered by alluvium along all its contacts (pl. 1). The Nummulites do not provide an unequivocal answer, as their internal structure has been largely obliterated by recrystallization; nevertheless, their general appearance is compatible with an early to middle Eocene age (K. N. Sachs, oral commun., 1970). The equivalent unit in the HekimhanHasançelebi area very likely is the nummulitic "Eozän-Kalke" described by Izdar (Izdar, 1963, p. 14-15).

\section{SEDIMENTARY SEQUENCE OF INCECIĞIN DERE}

A sequence of conglomerate, sandstone, and subordinate limestone, marl, and mudstone occupies a large part of the eastern half of quadrangle K39- $\mathrm{a}_{2}$, the northwestern corner of K39- $\mathrm{a}_{1}$, and a tract between Darili and Germeç Tepe $\left(\mathrm{K} 39-\mathrm{a}_{1}\right)$. The same sequence is widely distributed between Kuluncak and Hekimhan, $30 \mathrm{~km}$ to the east, as well as in the Hekimhan-Hasançelebi area, where it has been referred to as "Detritische bunte Serie" (detrital multicolored series) by Izdar (1963, p. 15-17). The sedimentary sequence extends northward at least as far as Sivas and southward to about $30 \mathrm{~km}$ south of Hekimhan; thus, it is a unit of regional importance. Foraminiferal assemblages (see under this heading the section on "Age") indicate a middle to late Eocene age for the sequence.

No formal name has previously been proposed for this unit, and none is proposed here, as neither the top nor the bottom of the sequence could be identified. Izdar's (1963) informal designation "Detritische bunte Serie" appears inappropriate because (1) the term "series" is ambiguous as a rock unit, and (2) all the rocks of the sequence are not detrital. The informal name "sedimentary sequence of Inceciğin Dere" ("Inceciğin Dere sequence") will be used in this report. The unit is named after Inceciğin Dere, which crosses extensive outcrops of the sequence in the southeastern part of K39-a .

The sedimentary sequence of Inceciğin Dere is here divided into three units: (1) a lower, relatively thin unit of conglomerate, sandstone, and mudstone; (2) a middle unit of limestone; and (3) an upper, thick unit of conglomerate, sandstone, and subordinate limestone, calcareous mudstone, and marl. These subunits are discussed below. 
Lower unit.-The lower unit is exposed mainly on the southwest flank of Erzincan Kuzu Tepe and on the northwest side of Inceciğin Tepe. Small patches rest on serpentine northwest of Kuluncak and north of Yunnuk, and the lowermost sandstoneconglomerate beds of the section south of Karlik (northwest corner of the area) have been tentatively assigned to this unit.

Southwest of Erzincan Kuzu Tepe, the lower unit has an estimated maximum thickness of about $250 \mathrm{~m}$. The base, resting unconformably on the serpentinite-gabbro complex, consists of massively bedded cobble conglomerate including mafic and intermediate volcanic rocks, limestone, jasper, serpentinite, and gabbro. The cobble conglomerate grades upward to interlayered pebble conglomerate and sandstone typical of the upper unit. The sandstone-conglomerate, in turn, grades upward to greenish-gray mudstone. The middle limestone unit conformably overlies the lower unit; $500 \mathrm{~m}$ north of Köyderesi village, the contact is gradational over several meters of interbedded limestone and sandstone-conglomerate.

Middle limestone unit.-The middle limestone unit is best exposed on Erzincan Kuzu Tepe, where it has a maximum estimated thickness of about $500 \mathrm{~m}$. Limestone around Yunnuk, Inceciğin Tepe, Döllükgüney Tepe, and Kabak Tepe is included in this unit, as are the larger limestone sequences around Darll and northwest of Boyal1. On a broad scale, this limestone forms thick lenses between the lower and upper sandstone-conglomerate units.

In the section at Erzincan Kuzu Tepe and to the southeast, the limestone is typically fine grained and somewhat chalky, well bedded (individual layers $2-20 \mathrm{~cm}$ thick), and ranges from white to beige to light brown. Commonly, it contains spicules and spearlike siliceous (?) forms which are possibly of organic origin; these locally result in a distinctive wormy pattern having an appearance not unlike that of eutaxitic texture in a vitric welded tuff. No distinct fossils, however, were found. Locally, the texture is porous to vuggy.

The limestone is everywhere at least slightly folded into open folds having amplitudes of several centimeters and widths of 1-3 m. Locally the limestone is much more intensely folded and even overturned. Such deformation is attributed largely to tectonic movements of underlying serpentinite during the Tertiary,

A large limestone mass southwest of Daril generally similar to that described above is included in the middle limestone unit. Limestone beds 1-3 m thick ( not shown on pl. 1) interbedded with sandstone and conglomerate between Darılı and Germeç Tepe may 
represent the middle limestone member or may be part of the upper unit. Massively bedded, pale-colored, fine-grained unfossiliferous limestone northwest of Boyalı is likewise assigned to the middle unit. At the latter locality, the thickest limestone bed has a maximum estimated thickness of $150 \mathrm{~m}$, and several smaller lenses crop out stratigraphically below that bed.

The lower contact of the middle limestone unit, as seen around Erzincan Kuzu Tepe, is conformable, as described earlier. Northwest of Yunnuk, and also northwest of Boyal, the limestone is conformably overlain by the upper unit of the Incecigin Dere sequence. Southeast of Yunnuk, the contact between the two units is mostly faulted.

Upper unit.-This unit, by far the thickest and most extensive of the Inceciğin Dere sequence, consists mostly of interbedded sandstone and conglomerate and subordinate limestone. This unit underlies deeply dissected plains in the southeastern and northeastern parts of the mapped area; between the villages of Iğdelidere and Sütlüören, the unit appears to have a minimum thickness of 2,000 m. Sandstone and conglomerate between Daril and Germeç Tepe, and northwest of Boyall, are also included in the upper unit.

In the gently rolling, mostly cultivated terrain in the northern part of $\mathrm{K} 39-\mathrm{a}_{2}$, it becomes difficult to distinguish between alluvium and poorly exposed sandstone and conglomerate of the upper unit, which also underlies the area. A "probable bedrock" subunit has been used for the Inceciğin Dere rocks in this area in places where outcrops cannot be found, but abundant pebbles and cobbles indicate the underlying conglomerate. The placement of contacts, especially between alluvium and probable bedrock, has necessarily been somewhat arbitrary in places.

As typically exposed in the eastern part of K39- $\mathrm{a}_{2}$, beds of the upper unit have a characteristic reddish color. Sandstone and conglomerate are interbedded in layers $50 \mathrm{~cm}$ to $3 \mathrm{~m}$ thick and show minor crossbedding, channeling, and other evidence of strong current action during deposition. The conglomerate consists of pebbles and cobbles having a maximum diameter of about $10 \mathrm{~cm}$. These include both black and light-gray to tan limestone, darkgray porphyritic volcanic rock, and subordinate jasper, gabbro, and serpentinite; the last three constituents are more abundant near contacts with the serpentinite-gabbro complex. The black limestone could represent either the limestone of Karapınar Dere or the dark facies of the limestone of Çaltepe, and the lightcolored limestone resembles the middle unit of the Inceciğin Dere 
sequence. The source of the volcanic rocks is problematical, as the only fairly similar type known in the area is the younger postEocene volcanic sequence.

The sandstone is typically medium grained and well sorted; a multicolored appearance is imparted by mineral grains of different colors. A sample studied under the microscope contains quartz, trachyte, andesite, serpentine, hornblende, pyroxene, opaque minerals, and clastic calcite in a calcite matrix; another consists almost entirely of trachyte fragments, indicating that trachyte has provided a local source for the sandstone.

Locally interbedded with the sandstone-conglomerate sequence are at least two kinds of limestone in layers $20-100 \mathrm{~cm}$ thick: (1) white to cream-colored, unfossiliferous, locally porous and suggestive of travertine, elsewhere platy; and (2) punky, light-brown to chocolate colored, containing abundant small white gastropods that are not specifically identifiable but that are definitely freshwater types (N. F. Sohl, written commun., 1970). Rare intercalated gray-green siltstone and calcareous mudstone (for example, southwest of Kizilpinarin Çal Tepe, eastern edge of K39-a loc. 6 on pl. 1) contain abundant Foraminifera and gastropods.

Several variations were noted in the upper unit of the Inceciğin Dere sequence in other parts of the mapped area. Northeast of Erzincan Kuzu Tepe above Erzincan Dere, conglomerate is light gray, consists dominantly of chert and subordinate limestone, and is interbedded with gray-brown calcareous siltstone. Northwest of Darılı, conglomerate is generally similar to that near Inceciğin Dere, but locally there are lenses of dark volcanic conglomerate in a sandy matrix. Northwest of Boyal, the sandstone-conglomerate sequence is highly calcareous and contains abundant Nummulites. At one locality in Derin Dere at the western edge of K39-a (loc. 9, pl. 1), Nummulites as much as $5 \mathrm{~cm}$ in diameter actually clasts of the conglomerate.

Beds of the Inceciğin Dere sequence typically are moderately tilted and locally folded. In the northeastern part of the K39- $\mathrm{a}_{2}$ quadrangle, sandstone-conglomerate beds are nearly monoclinal, strike mostly east, and dip north. In the southwestern part of this quadrangle, the beds show variable attitudes and tend to dip away from bordering blocks of older rocks, probably as the result of uplift related to emplacement of serpentinite. In the northwestern corner of $\mathrm{K39}-\mathrm{a}_{1}$, the beds strike northwest and dip northeast, generally parallel to the older formations to the south. 
Age.-The following fossils from several localities within the sedimentary sequence of Inceciğin Dere have been identified by K. N. Sachs, formerly U.S. Geological Survey.

\begin{tabular}{cl}
$\begin{array}{c}\text { Location on } \\
\text { plate } 1\end{array}$ & \multicolumn{1}{c}{\begin{tabular}{c}
\multicolumn{1}{c}{ Description } \\
6
\end{tabular}} \\
& $\begin{array}{l}\text { Nummulites striatus (Bruguiére) } \\
\text { Assilina exponens (Sowerby) }\end{array}$ \\
7 & $\begin{array}{l}\text { Nummulites sp. cf. N. gallensis (Heim) } \\
\text { Assilina sp. cf. A. exponens (Sowerby) }\end{array}$ \\
& Nummulites brongniarti d'Archiac and Haime \\
8 & Nummulites sp. cf. N. striatus (Bruguiére) \\
& Discocyclina sp. \\
& Nummulites sp.
\end{tabular}

This assemblage indicates a range of middle to late Eocene (K. N. Sachs, written commun., 1970). All the Foraminifera were obtained from calcareous sandstone and mudstone, siltstone, or limestone, and hence should reflect the age of the containing rocks. Izdar (1963, p. 15-17), on the basis of Lutetian (middle Eocene) assemblages found in conglomerate pebbles and cobbles in the "Detritische bunte Serie," concluded that the sequence must be younger than middle Eocene, probably Oligocene. Izdar also (1963, p. 17) maintained that, in the Kuluncak region, the sequence discordantly overlies middle Eocene strata; we found no indications of this.

Origin.-The Inceciğin Dere sequence is unusual in the great thickness and extent of the upper conglomerate-sandstone unit; the juxtaposition of marine and freshwater sediments; and the considerable variations both in lithofacies and biofacies from place to place. The very thick sandstone-conglomerate sequence indicates prolonged deposition in a littoral environment during a period of active erosion; interbedded foraminiferal mudstone, sandstone, and limestone (near the bottom of the section?) confirm that the environment was marine. Nevertheless, limestone beds containing freshwater fossil assemblages intercalated with conglomerate (near the top of the section?) indicate that the depositional environment occasionally changed to lagoonal if not lacustrine. The rather thick, lenticular unfossiliferous limestone unit appears to be a shallow marine deposit.

\section{LIMESTONE OF YAPALAKLI TEPE}

Subhorizontal limestone caps the upper unit of the Inceciğin Dere sequence with discordant contact at Bozcakale Tepe, Yapalakl Tepe, Cincıklı Tepe, south of Ağcahüyük Tepe, and at several 
other localities. At Yapalakl Tepe, for which this unit is informally named, middle Miocene volcanic rocks are found between the two limestone units.

Limestone underlying Bozcakale Tepe and Yapalakl ${ }_{1}$ Tepe is typically porous and irregularly textured, and has a high concentration of spicules and spearlike froms already described for the middle limestone unit of the Inceciğin Dere sequence. Locally, as along the southern boundary of Yapalaklı Tepe, abundant fossil leaves show that this limestone is a freshwater deposit. Elsewhere, as at Cincıklı Tepe and south of Ağcahüyük Tepe, the limestone is dense, nonporous, and locally thinbedded and thus resembles the limestone underlying Erzincan Kuzu Tepe. Strata generally are nearly horizontal or gently dipping, but local dips of as much as $45^{\circ}$, and varying strikes, were observed.

No diagnostic fossils were found in the limestone of Yapalakl Tepe, but its age is bracketed between about 18.7 m.y. and 14.1 m.y. by volcanic rocks that it overlies and that cut it (see section "Age" under "Middle to upper Miocene volcanic sequence and see "Compositional and age relationships of the igneous rocks"). The limestone is tentatively regarded as older than the dolomite of Ozzbek (see below), in view of the greater degree of deformation of the limestone relative to the dolomite.

\section{DOLOMITE OF ÖZBEK}

White punky dolomite having very well developed flaggy bedding overlies the post-Eocene volcanic series in the vicinity of Ozzbek and is here informally designated "dolomite of Özbek." The dolomite covers an area approximately $3 \mathrm{~km}$ long and 1 to 2.5 $\mathrm{km}$ wide between Germeç Tepe and Yüce Tepe, where attitudes indicate a gentle northwest-trending basin. Similar dolomite also crops out south of this area on the peak of Akseki Tepe and part of the low ridge to the northwest. Its extent outside the mapped area is unknown. Its thickness is likewise unknown but probably does not exceed a few tens of meters.

This dolomite has been regarded as volcanic tuff (Ayan, see section "Unpublished reports"), which indeed it resembles superficially. Microscopic examination however, shows it to be pure, finely crystalline carbonate, confirmed as dolomite by X-ray diffraction analysis.

As no fossils were found in the dolomite, its exact age cannot be determined. Its stratigraphic position, however, shows it to be post-Eocene, and in view of its slight deformation, it may be much younger, perhaps Pliocene. In any case, the dolomite indi- 
cates the presence of shallow local marine basins after the middle Tertiary volcanism.

\section{TERTIARY OR QUATERNARY}

\section{UPPER TERTIARY OR QUATERNARY CONGLOMERATE AND} TRAVERTINE

More or less tightly cemented conglomerate, in some places associated with travertine, is exposed in many localities throughout quadrangle K39- $\mathrm{a}_{2}$, and minor exposures are found in K39-a Some of the larger conglomerate outcrops differ considerably from each other in detail, and positive correlation among the various types is not possible at this time. These conglomerates are generally surficial, and most are near horizontal, although local tilting is evident. Hence, these conglomerates appear to be relatively young, but they are almost certainly older than the Quaternary terrace gravels that are widespread in K39-a .

Poorly sorted, well-cemented conglomerate underlying Kabak Tepe and Yanikharman Tepe near Dereköy consists mostly of cobbles and boulders of limestone as much as $50 \mathrm{~cm}$ in diameter, and subordinate volcanic, mafic, and other rock types. Locally discernible bedding dips as much as $45^{\circ}$. The structural position of this conglomerate under the limestone of Yapalakl Tepe (pl. 1) indicates that this conglomerate may actually be equivalent to the Inceciğin Dere sequence, but because of doubtful correlation and the marked difference from the latter unit, this conglomerate has been included with the younger ones.

Near-horizontal conglomerate around Blyıkboğazi village and southward along Yunnuk Dere is unconsolidated, moderately sorted, and consists mostly of andesite cobbles and boulders evidently derived from the Miocene volcanic sequence. About $400 \mathrm{~m}$ east-northeast of Yunnuk, poorly sorted, moderately cemented conglomerate containing limestone boulders as much as $1 \mathrm{~m}$ across forms a bluff capped by $20 \mathrm{~m}$ of cavernous travertine; lesser exposures of generally similar conglomerate are found north of Yunnuk and northwest of Payaml Tepe. Well-sorted limestone cobble conglomerate in a calcareous matrix crops out around Ortapınar Mezraası and along Körçepınar Dere to the north.

\section{QUATERNARY}

TERRACE GRAVEL

Small to large cappings of terrace gravel, presumed to be Quaternary, are found throughout quadrangle K39- $\mathrm{a}_{1}$. The largest of these are on the flat summits of Ardıçlı Tepe and Harmangediği 
Sirt; smaller gravel caps are found on Yüce Tepe (pl. 1, northwest corner), Ohlaz Tepe, Akkaya Tepe, Boztepe, and in several other places. The gravels range from pebbles to boulders and consist mainly of various kinds of limestone and subordinate volcanic rocks, chert, and mafic and ultramafic components. Although a detailed survey was not made, the average bulk composition of the gravel does not appear to vary much, irrespective of the underlying rock; hence, the gravel must have undergone sufficient transportation and winnowing to be fairly homogenized. The thickness of individual gravels could not usually be determined; the gravel cap exposed in a section on the east side of Ohlaz Tepe is estimated to be 5 to $10 \mathrm{~m}$ thick.

The larger gravel layers, for example, those on Ardiçlı Tepe, are essentially flat lying, but some of the smaller ones, for example, the cap on Ohlaz Tepe, are tilted as much as $6^{\circ}$. Together with the distribution pattern of the gravels, these observations suggest significant uplift and tilting, followed by dissection, of the region since the gravel was deposited.

\section{LANDSLIDES}

Landslides are abundant in the mapped area and affect almost all the lithologic units. Sliding and slumping are especially pronounced south of Yunnuk, a region marked by many fractures and normal faults in the bedrock. Another area of abundant landslides is in the fractured Inceciğin Dere sequence around Darıli and to the northwest. A fan-shaped area about $1.3 \mathrm{~km}$ long and $1.3 \mathrm{~km}$ wide on the east side of Çökülge Dere is interpreted as a single slide. A slide in serpentinite on the southeast side of Salloğlanın Dere (southwestern corner of K39-a $\mathbf{a}_{z}$ ) took place in August 1969 after heavy rains.

\section{ALLUVIUM}

Quaternary alluvium, besides covering the beds of major streams and their tributaries, also covers large areas of low relief, such as the northern part of K39-a $\mathrm{a}_{2}$. The difficulty of distinguishing between alluvium and probable bedrock of the Inceciğin sequence in this area has been previously mentioned.

\section{INTRUSIVE AND VOLCANIC ROCKS}

\section{PRE-CRETACEOUS OR CRETACEOUS SERPENTINITE-GABBRO COMPLEX}

Nature and distribution.-A complex of ultramafic and mafic rocks underlies much of the Kuluncak-Sofular area. The complex 
includes serpentinite that contains rare relicts of peridotite, scattered bodies of gabbro, and local lenses of quartz-rich rock that may represent silicified gabbro. In many places, especially in the eastern and central parts of the area, serpentinite is covered by a weathered crust of silica-carbonate rock that locally contains small masses and veins of iron oxide. As serpentinite and gabbro predominate in the complex, it is referred to collectively as the serpentinite-gabbro complex.

The serpentinite-gabbro complex in this region was first discussed by Blumenthal (see section "Unpublished reports"), who recognized it as a basement upon which Upper Cretaceous and younger strata had been deposited; later, these strata were eroded from domes and anticlinal axes, especially in the Hekimhan area and southeast along the valley of Kuruçay (Dry River). The massif that extends westward from Kuluncak, called "spur of Kuluncak" by Blumenthal (see section "Unpublished reports") is the largest area of ultramafic-mafic rocks in the region.

Serpentinite and peridotite.-The ultramafic rocks range in color from nearly black through dark green, gray green, light tan, or light gray. Random specimens examined under the microscope typically consist almost wholly of fibrous or flaky serpentine and recognizable pseudomorphs of pyroxene and olivine. Individual serpentine species were not determined. Some rocks contain remnants of original silicate minerals, but relatively unserpentinized rocks are rare. Finely crystalline carbonate (nagnesite or dolomite) is locally abundant, especially near contacts with the silicacarbonate cap rock. Dusty to granular disseminated opaque material present in most samples probably is partly magnetite and partly chromite. Compositions of serpentinite and partly serpentinized peridotite are shown in table 1 , analyses 1 and 2 .

Gabbro associated with serpentinite-Gabbro of three typesunaltered gabbro, metagabbro, and silicified gabbro-forms more or less discrete bodies within serpentinite in the area. Unaltered gabbro is medium grained, mesocratic, and consists dominantly of highly calcic plagioclase and clinopyroxene and subordinate olivine. It forms masses having roughly elliptical surface expression, underlying Oturak Tepe, about $1 \mathrm{~km}$ southwest of Sofular; Killiziyaret Tepe, about $3.5 \mathrm{~km}$ southeast of Hamalçayı village near the southern boundary of K39- $\mathrm{a}_{1}$; and other, smaller masses. The gabbro forms conspicuous bouldery outcrops; contact with adjacent, poorly exposed serpentinite appears to be sharp and nongradational. Structures in the serpentinite are almost everywhere obscured; effects of contact metamorphism are lacking. Thus, it 
TABLE 1.-Chemical analyses of igneous

[ Rapid-rock analyses by Lowell Artis, H. Smith, G. Chloe, J. Glenn, P. Elmore, and J.

\begin{tabular}{|c|c|c|c|c|c|c|c|c|c|c|}
\hline & \multicolumn{4}{|c|}{ Serpentinite and gabbro } & \multicolumn{4}{|c|}{ Alkalic diabase } & & \multirow[b]{2}{*}{10} \\
\hline & 1 & 2 & 3 & 4 & 5 & 6 & 7 & 8 & & \\
\hline & & & & & & & & \multicolumn{3}{|c|}{ Chemical analyses } \\
\hline 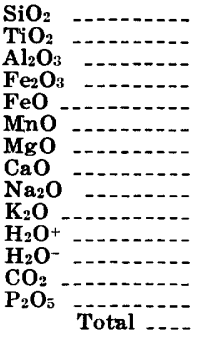 & $\begin{array}{c}38.9 \\
.02 \\
.62 \\
3.3 \\
2.7 \\
.07 \\
36.8 \\
.28 \\
.03 \\
.06 \\
11.7 \\
1.5 \\
4.6 \\
.03 \\
100\end{array}$ & $\begin{array}{c}39.0 \\
.02 \\
.31 \\
3.6 \\
3.7 \\
.12 \\
39.5 \\
.83 \\
.02 \\
.06 \\
11.8 \\
.73 \\
.30 \\
.03 \\
100\end{array}$ & $\begin{array}{c}48.3 \\
.07 \\
19.6 \\
0.60 \\
2.4 \\
.00 \\
9.8 \\
17.6 \\
.63 \\
.03 \\
1.4 \\
.09 \\
.02 \\
.01 \\
100\end{array}$ & $\begin{array}{c}48.3 \\
.11 \\
16.8 \\
.70 \\
3.3 \\
.00 \\
11.5 \\
17.8 \\
.62 \\
.01 \\
1.3 \\
.04 \\
.02 \\
.01 \\
100\end{array}$ & $\begin{array}{c}48.6 \\
.40 \\
18.1 \\
3.7 \\
3.4 \\
.10 \\
2.8 \\
9.7 \\
3.4 \\
1.6 \\
1.1 \\
1.3 \\
5.6 \\
.28 \\
100\end{array}$ & $\begin{array}{c}46.9 \\
1.4 \\
15.8 \\
6.8 \\
2.2 \\
.19 \\
1.7 \\
7.2 \\
3.4 \\
4.9 \\
1.6 \\
1.2 \\
5.3 \\
.62 \\
99\end{array}$ & $\begin{array}{c}47.7 \\
1.0 \\
17.6 \\
2.5 \\
5.1 \\
.11 \\
3.0 \\
7.5 \\
2.3 \\
3.8 \\
2.1 \\
2.1 \\
4.5 \\
.45 \\
100\end{array}$ & $\begin{array}{c}44.7 \\
1.2 \\
17.0 \\
2.6 \\
6.1 \\
.30 \\
3.6 \\
9.3 \\
3.0 \\
3.0 \\
2.2 \\
2.2 \\
5.9 \\
.45 \\
100\end{array}$ & \begin{tabular}{|l}
61.6 \\
.15 \\
17.1 \\
.40 \\
.64 \\
.06 \\
1.1 \\
2.0 \\
.80 \\
12.8 \\
.42 \\
.03 \\
2.6 \\
.02 \\
100
\end{tabular} & $\begin{array}{c}63.4 \\
.17 \\
16.5 \\
2.7 \\
.36 \\
.01 \\
.57 \\
1.1 \\
2.0 \\
11.2 \\
.77 \\
.11 \\
1.4 \\
.02 \\
100\end{array}$ \\
\hline
\end{tabular}

Norms

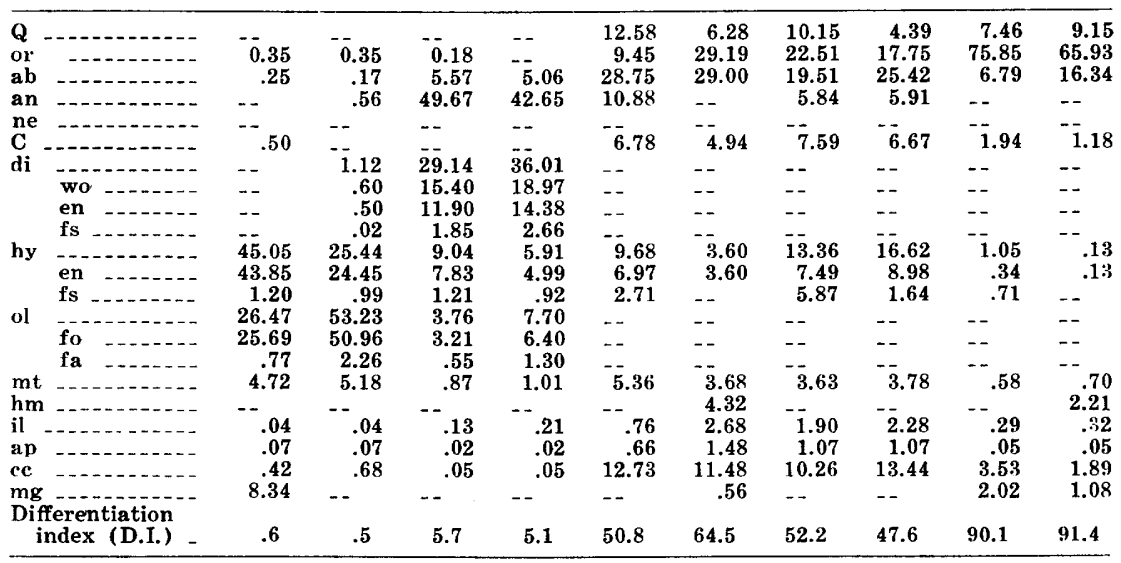

EXPLANATION FOR TABLE 1

1 Sample 69-GWL-4B/2-1. Serpentinite, directly above Kuluncak-Sofular road on point of ridge trending southwest from Göksivri Tepe, $2 \mathrm{~km}$ west-southwest of Kuluncak. Serpentine, disseminated opaque minerals, and carbonate. Also contains 0.36 percent $\mathrm{Cr}$ and 0.16 percent $\mathrm{Ni}$.

2 Sample 69-GWL-106B. Partly serpentinized peridotite, southeast side of Hamalcayı Dere on northwest slope of Tuztasi Tepe, $3.2 \mathrm{~km}$ southwest of Sofular. Serpentine and relict orthopyroxene and olivine, disseminated opaque minerals. Also contains 0.34 percent $\mathrm{Cr}$ and 0.17 percent $\mathrm{Ni}$.

3 Sample 69-GWL-133B. Gabbro, Oturak Tepe, $1 \mathrm{~km}$ southwest of Sofular. Plagioclase (est. An:m), clinopyroxene, partly serpentinized olivine.

4 Sample 69-GWL-134B. Gabbro, Killiziyaret Tepe, $6 \mathrm{~km}$ south of Sofular. Plagioclase (est. Ansa), clinopyroxene, olivine.

5 Sample 69-GWL-122B. Diabase dike, west bank of Darll Dere, $1.0 \mathrm{~km}$ north of Tohma Suyu. Plagioclase ( rims Ano-20, cores An;n-15), clinopyroxene, chlorite, calcite. opaque minerals.

6 Sample 69-GWL-37A-1. Potassic diabase, $200 \mathrm{~m}$ south of Dereköy. Plagioclase (An 10-15) in groundmass of potassium feldspar (?); opaque minerals about 5 percent.

7 Sample 69-GWL-37A-4. Diabase, approximately $100 \mathrm{~m}$ north of preceding location, same body. Plagioclase $\left(A_{n} n_{i 3}\right)$, clinopyroxene, biotite, chlorite, carbonate.

8 Sample 69-GWL-129-3. Diabase sill, about $20 \mathrm{~m}$ uphill from beginning of section No. 1 , Sofugediği area. Plagioclase (rims $A n_{10}$, cores $A n_{F-1 n}$ ), biotite (approx. 5 percent), chlorite, carbonate, opaque minerals.

9 Sample 69-GWL-124A. Trachyte, north side of Sallioğlanın Dere near its confluence with Tohma Suyu, $2.75 \mathrm{~km}$ west-northwest of Kuluncak. Sanidine plus small amounts of disseminated quartz and secondary carbonate.

10 Sample 69-GWL-27D-2. Trachyte, northeast side of road about $3 \mathrm{~km}$ west of Kuluncak, across from mouth of Sallioğlanın Dere. Same mineralogy as preceding sample.

11 Sample $69-\mathrm{GWL}-117 \mathrm{D} / 2$. Marginal phase of trachyte porphyry near contact with Sofular Formation, Kizlburun Sirt (ridge), $4 \mathrm{~km}$ northwest of Sofular, north side of Tohma 
rocks in the Kuluncak-Sofular area

Kelsey under the direction of Leonard Shapiro, U.S. Geological Survey, Washington, D.C.]

\begin{tabular}{|c|c|c|c|c|c|c|c|c|c|c|c|}
\hline \multicolumn{7}{|c|}{ Trachyte, trachyandesite, and syenite } & \multicolumn{5}{|c|}{ Andesite, basalt, and dacite } \\
\hline 11 & 12 & 13 & 14 & 15 & 16 & 17 & 18 & 19 & 20 & 21 & 22 \\
\hline \multicolumn{12}{|c|}{ (weight percent) } \\
\hline $\begin{array}{c}58.6 \\
.49 \\
18.7 \\
1.9 \\
1.9 \\
.00 \\
1.3 \\
1.6 \\
6.2 \\
6.0 \\
2.6 \\
.37 \\
.24 \\
.08 \\
100\end{array}$ & $\begin{array}{c}61.8 \\
1.1 \\
17.4 \\
4.6 \\
.48 \\
.05 \\
.50 \\
1.5 \\
5.7 \\
5.2 \\
.81 \\
.39 \\
.05 \\
.30 \\
100\end{array}$ & $\begin{array}{c}62.3 \\
.62 \\
17.0 \\
4.9 \\
.52 \\
.11 \\
.32 \\
1.1 \\
6.0 \\
5.6 \\
.72 \\
.21 \\
.24 \\
.13 \\
100\end{array}$ & $\begin{array}{c}55.2 \\
.18 \\
20.5 \\
3.6 \\
1.5 \\
.14 \\
.36 \\
2.6 \\
8.2 \\
4.7 \\
.22 \\
.33 \\
.16 \\
.00 \\
100\end{array}$ & $\begin{array}{c}64.7 \\
.41 \\
18.3 \\
1.7 \\
.96 \\
.00 \\
.47 \\
1.0 \\
4.3 \\
5.9 \\
.93 \\
.67 \\
<.05 \\
.08 \\
99\end{array}$ & $\begin{array}{c}58.6 \\
.61 \\
18.9 \\
5.4 \\
1.0 \\
.30 \\
1.1 \\
1.2 \\
4.2 \\
5.1 \\
2.3 \\
.93 \\
<.05 \\
.18 \\
100\end{array}$ & $\begin{array}{c}58.0 \\
.48 \\
18.3 \\
1.9 \\
1.2 \\
.00 \\
1.4 \\
2.5 \\
2.6 \\
9.3 \\
1.9 \\
.33 \\
2.2 \\
.14 \\
100\end{array}$ & $\begin{array}{c}49.1 \\
1.6 \\
15.9 \\
1.5 \\
8.1 \\
.17 \\
7.8 \\
8.0 \\
3.5 \\
1.2 \\
1.4 \\
.82 \\
<.05 \\
. .36\end{array}$ & $\begin{array}{c}59.6 \\
1.0 \\
16.9 \\
2.7 \\
3.6 \\
.12 \\
2.8 \\
5.7 \\
3.1 \\
2.6 \\
1.3 \\
.25 \\
<.05 \\
.21 \\
100\end{array}$ & $\begin{array}{c}58.2 \\
.90 \\
17.3 \\
3.9 \\
2.6 \\
.12 \\
2.8 \\
6.1 \\
3.4 \\
2.3 \\
1.0 \\
.79 \\
<.05 \\
.21 \\
100\end{array}$ & $\begin{array}{c}57.8 \\
.66 \\
16.2 \\
2.9 \\
2.2 \\
.06 \\
2.2 \\
7.2 \\
3.1 \\
2.5 \\
2.2 \\
1.0 \\
1.8 \\
.22 \\
100\end{array}$ & $\begin{array}{c}67.7 \\
.40 \\
16.8 \\
2.7 \\
.40 \\
.09 \\
1.2 \\
4.3 \\
4.4 \\
1.3 \\
.43 \\
.08 \\
<.05 \\
.19 \\
100\end{array}$ \\
\hline
\end{tabular}

\section{Norms-Continued}

\begin{tabular}{|c|c|c|c|c|c|c|c|c|c|c|c|}
\hline $\begin{array}{r}35.38 \\
44.77 \\
4.26\end{array}$ & $\begin{array}{r}5.78 \\
30.77 \\
48.29 \\
5.17\end{array}$ & $\begin{array}{r}4.21 \\
33.17 \\
50.89 \\
2.92\end{array}$ & $\begin{array}{r}27.87 \\
37.40 \\
5.27\end{array}$ & $\begin{array}{r}13.89 \\
34.88 \\
36.40 \\
4.12\end{array}$ & $\begin{array}{r}11.10 \\
30.19 \\
35.60 \\
4.47\end{array}$ & $\begin{array}{r}5.88 \\
54.77 \\
21.85 \\
--\end{array}$ & $\begin{array}{r}7.13 \\
29.77 \\
24.26\end{array}$ & $\begin{array}{l}15.07 \\
15.37 \\
26.24 \\
24.52\end{array}$ & $\begin{array}{l}13.80 \\
13.63 \\
28.85 \\
25.22\end{array}$ & $\begin{array}{l}16.72 \\
14.77 \\
26.22 \\
22.89\end{array}$ & $\begin{array}{r}26.79 \\
7.68 \\
37.22 \\
19.77\end{array}$ \\
\hline 4.12 & -- & $=$ & 17.46 & & -- & $\cdots$ & -- &.- & $\ldots$ & -- & -- \\
\hline .44 & .50 & -. & & 3.33 & 4.84 & 3.96 & & $\ldots$ & 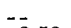 & -- & .91 \\
\hline-- & -- & .13 & 1.94 & -- & -. & -. & 10.54 & 1.67 & 2.53 & -. & -. \\
\hline-- & -- & .07 & 1.04 & -- & -- & -- & 5.4 & .8 & 1. & -. & -. \\
\hline- & -- & .06 & .90 & - & -- & - & 3.2 & .5 & 1.13 & -- & -. \\
\hline-- & -- & -- & -- & & - & - & 1.8 & .2 & .05 & - & -- \\
\hline -- & 1.25 & .74 & -. & 2.42 & 2.74 & 2.40 & 4. & 9.1 & 6.11 & 6.1 & 2.99 \\
\hline -- & 1.25 & .74 & -- & 2.42 & 2.7 & 2.40 & 2 . & 6.4 & 5.86 & 5.48 & 2.99 \\
\hline & - & - & -- & -- & -- & -- & 1. & 2.71 & .24 & .66 & -. \\
\hline 3.12 & 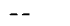 & - & -- & -- & - & -- & 15.62 & -- & -- & $\ldots$ & -. \\
\hline 2.26 & -. & -- & -- & -- & - & -- & 9.52 & -. & -. & - & -. \\
\hline .86 & $\cdots$ & -- & & -- & -- & -- & 6. & & & & -- \\
\hline 2.75 & -. & .24 & 4.79 & 1.91 & 2.4 & 2.47 & 2.1 & 3.92 & 5.67 & 4.20 & .42 \\
\hline & 4.61 & 4.75 & .31 & .39 & 3.72 & .19 & 3.0 & & & & 2.41 \\
\hline .93 & 1.12 & 1.18 & .34 & .78 & 1.16 & .91 & .8 & 1.9 & 1.71 & 1.25 & .76 \\
\hline .19 & .71 & .31 & -. & .19 & .48 & .33 & .11 & .5 & .57 & .52 & .45 \\
\hline .55 & .11 & .55 & .37 & .11 & .11 & 3.92 & -. & .11 & .11 & 4.09 & .11 \\
\hline-- & -- & -- & -- & -- & -- & .90 & -- & -- & -- & -- & -- \\
\hline 84.3 & 84.8 & 88.3 & 82.7 & 85.2 & 76.9 & 82.5 & 36.9 & 56.7 & 56.3 & 57.7 & 71.7 \\
\hline
\end{tabular}

Suyu. Sanidine, albite, sodalite(?), aegirine, pargasite(?), carbonate, and unidentified altered groundmass.

12 Sample 69-GWL-90C-1. Trachyandesite, Demirlitas $650 \mathrm{~m}$ south of Yüce Tepe. Groundmass of sanidine and sodic plagioclase with plagioclase phenocrysts; $1-2$ percent biotite; disseminated opaque minerals.

13 Sample 69-GWL-90D. Trachyandesite, $800 \mathrm{~m}$ southeast of Yüce Tepe. Groundmass of sanidine with phenocrysts of sanidine and sodic plagioclase, about 1 percent biotite, disseminated opaque minerals.

14 Sample 69-GWL-53C. Alkalic syenite, Ardiclı area, $200 \mathrm{~m}$ southwest of Avlıya Dere, 3.75 km west of Başören village. Potassium feldspar, albite, sodalite(?), aegirine, and minor phlogopite.

15 Sample 69-GWL-79C. Slightly welded tuff, Sofular Formation, Sartas ridge $500 \mathrm{~m}$ north of Yünlüce. Clasts of sanidine, sodic plagioclase, and trachyte in partly devitrified groundmass.

16 Sample 69-GWL-80E. Slightly welded tuff, Sofular Formation, about $2 \mathrm{~km}$ northwest of Yünlüce and $500 \mathrm{~m}$ south of Kale Mevkii. Clasts are mostly sodic plagioclase in glaissy eutaxitic groundmass.

17 Slightly welded tuff, Sofular Formation, north side of Tohma Suyu. As preceding, but clasts are most sanidine.

18 Basalt, Ardiclı area south of Karapinar Dere, $4 \mathrm{~km}$ west of Basören. Plagioclase (Añz-sz), titaniferous augite, and olivine.

19 Andesite, volcanic plateau $3 \mathrm{~km}$ east-southeast of özbek. Plagioclase (An5:3-81), hypersthene, and augite in hemihyaline groundmass.

20 Andesite, volcanic plateau $2.5 \mathrm{~km}$ east-northeast of özbek. Plagioclase (An $\left.\mathbf{n}_{5}\right)+6$ ), hypersthene, and hornblende in hemihyaline groundmass.

21 Tuff-breccia, north side of Deregözü Dere, $600 \mathrm{~m}$ southwest of summit of Germec Tepe. Plagioclase (An:5-65), hornblende, hypersthene, zoisite (?), and augite-bearing andesite.

22 Dacite, summit of Ağcahüyük Tepe, $2.5 \mathrm{~km}$ southeast of Iğdelidere. Plagioclase (andesinelabradorite) and oxyhornblende in hemihyaline groundmass. 
is not certain whether the gabbro bodies represent discrete intrusions or whether they are tectonic blocks. Both may be true in different places. Smaller, silicified gabbro bodies, on the other hand, locally show evidence of intrusion (see below).

Two analyses of unaltered gabbro (table 1, analyses 3 and 4) show conspicuously high $\mathrm{CaO}$ together with low $\mathrm{FeO}$ and very low $\mathrm{Na}_{2} \mathrm{O}, \mathrm{K}_{2} \mathrm{O}$, and $\mathrm{TiO}_{2}$. Such gabbro compositions appear to be typical of alpine-type complexes (for example, see Thayer and Himmelberg, 1968; Thayer, 1971).

Gabbro showing evidence of retrograde metamorphism, in which pyroxene and plagioclase are partially replaced by pale actinolitic amphibole, crops out in some places, notably the area south and southwest of Camdere Başı Tepe (southwest part of K39- $a_{2}$ ). The extent of such metagabbro, and its relation to serpentinite, are unknown, but evidently its petrogenesis is somewhat different from that of the unaltered gabbro.

Small bodies of more or less silicified gabbro constitute a third distinct type in the area. These rocks are mesocratic to leucocratic, quartz rich, and have wavy foliation; they look much more like granitic gneiss than gabbro. Microscopic examination reveals a strongly sheared and granulated texture; replacements of plagioclase by quartz, hornblende, and biotite are generally present and are possibly secondary after original pyroxene. Potassium feldspar is present locally and mafic minerals are sparse or absent, resulting in a composition close to granite. Such rocks evidently are typical of Alpine ultramafic complexes (Thayer, 1967, esp. p. 227 ). Silicified gabbro, which is known only from the serpentinite southwest of Tohma Suyu, typically forms abruptly rising pluglike or lensoid masses less than $100 \mathrm{~m}$ in diameter. The conspicuous alinement of small plugs along the west side of Hamalcayı Dere and on the west-trending ridge north of Körmustafalar village marks possible fault zones. Gneissic gabbro of the two northermost plugs on the west side of Hamalçayı Dere east of Gökgüney Tepe is sharply bounded by serpentinite. On the south side of the northern plug over a distance of about $50 \mathrm{~m}$ are small outcrops of similar gneissic gabbro, partly equidimensional and partly tabular, which are so intimately intermingled with serpentinite that they form a kind of migmatite. These smaller outcrops are conspicuously coarse grained, locally pegmatoid, and contain hornblende crystals as much as $10 \mathrm{~cm}$ long. These features suggest intrusion of gabbro into a shear zone, possibly while shearing was in progress, and more or less contemporaneous silicification.

Along the ridge north of Körmustafalar, the elongation and alinement of similar gneissic, silicified gabbro bodies also sug- 
gests a fault zone, although other evidence for faulting is lacking. On the north side of Kai Dere, $1.5 \mathrm{~km}$ south of Yukarı Hamalçayı village, narrow lenses of silicified gabbro are definitely related to a fault zone, and the same is apparently true of northwest-striking lenses cropping out in a canyon $1 \mathrm{~km}$ west-southwest of Bicir village. These evidently late-formed rocks may represent normal igneous differentiates (Thayer, 1967, p. 232-234) injected into shear zones and subsequently altered by silica-rich fluids rising along the fractures.

Silica-carbonate cap rock.-Large parts of the serpentinitegabbro complex are covered by a characteristic red-brown crust composed mostly of jasperoid silica and subordinate but locally abundant calcite, scattered veins of quartz and white dolomite, and local concentrations of massive or disseminated magnetite. These magnetite accumulations, which represent the only iron deposits in the area, are discussed in the section on "Iron prospects." The silica-carbonate crust may form craggy outcrops as much as 30-40 m thick, which can be recognized from a distance, although these rocks may be confused with craggy trachyte of the region. Massive silica-carbonate crust (dense, red stippled pattern on pl. 1) is well shown north of Kuluncak, northeast and north of Darll village, and elsewhere. A thin and much less conspicuous crust (light red stipple on pl. 1) covers much of the remainder of the broad serpentinite belt between Kuluncak and Kizilok Boynu Tepe. The extensive serpentinite exposures southwest of Tohma Suyu are mostly free of silica-carbonate crust. The differential distribution of silica-carbonate rock over serpentinite could be explained either by differential erosion of the crust in different areas, or by failure of the crust to form at all in some places. The distribution of the siliceous crust appears to be unrelated, or only incidentally related, to zones of faults or fractures.

The silica-carbonate crust typically is red-brown aphanitic to granular jasperoid rock locally having a brecciated appearance caused by angular remnants of partly replaced serpentinite. Toward contacts with serpentinite, the crust becomes increasingly porous and has boxwork structure consisting of septa of silica and carbonate that represent fracture fillings in the original serpentinite. The contact, which is well exposed in many places, grades from unaltered serpentinite to jasperoid rock through a distance of about $1 \mathrm{~m}$. Partly eroded exposures of the silica-carbonate crust reveal that the contact with underlying serpentinite closely follows the present topography. 
The relationships described above clearly show that the silicacarbonate rock has been produced by weathering of the serpentinite-gabbro complex. Such serpentinization may have been effected by meteoric water saturated with $\mathrm{CO}_{2}$ (and $\mathrm{SiO}_{2}$ ?) acting upon partly or wholly serpentinized rock; a possible reaction (Deer, Howie, and Zussman, 1963, p. 215) is

$$
\underset{\text { serpentine }}{\mathrm{Mg}_{3} \mathrm{Si}_{2} \mathrm{O}_{5}(\mathrm{OH})_{4}}+3 \mathrm{CO}_{2} \rightarrow 3 \mathrm{MgCO}_{3}+2 \mathrm{SiO}_{2}+2 \mathrm{H}_{2} \mathrm{O}
$$

(with some $\mathrm{Ca}$ in solution, the carbonate formed might be calcite or dolomite, as observed, instead of magnesite). Alternately, silica and carbonate may have formed in the course of the serpentinization itself (as observed in the Tavşanlı area of Turkey (Nebert, 1959a). Production of quartz (plus 14 A clay minerals and ferric oxides) by chemical weathering of serpentinite has been documented in a recent careful study in the eastern Piedmont of Maryland (Cleaves and others, 1974).

Earlier workers in the region (K. H. Rupprecht, unpub. data, 1960 ; G. van der Kaaden, unpub. data, 1961; Ilker, see section "Unpublished reports"; Ayan, see section "Unpublished reports") have assumed that the silica-carbonate rock overlying serpentine represented the older limestone (limestone of Karapınar Dere) that had been silicified during intrusion and serpentinization of the ultramafic rocks; Izdar (see section "Unpublished reports"; 1963) pictured metasomatism of the "limestone" as accompanying postintrusion serpentinization. The present study shows that these interpretations of the origin of the silica-carbonate cap rock are incorrect.

Contact relations.-Observed contact relations between serpentinite and younger rocks include (1) erosional contacts, (2) possible erosional contacts complicated by later uplift of serpentinite, and (3) faults that are equivalent to cold intrusive contacts. The three types are to some extent gradational and locally difficult to separate.

The most clear-cut example of an erosional contact, complicated only by later tilting, is shown by the Tökler conglomerate where it rests upon serpentinite in the southern part of $K 39-a_{1}$. A similar relationship is seen where locally deformed rocks of the Incecigin Dere sequence overlie silicified serpentinite north of Kuluncak and elsewhere.

Possible erosional contacts complicated by later uplift are best shown by the relations between the limestone of Karapinar Dere and underlying serpentinite. Such contacts have been assumed in the past (Ayan and Ilker, see section "Unpublished reports") to 
represent intrusion of serpentinite into limestone, resulting in widespread silicification of the limestone and other metamorphicmetasomatic effects. Observations from this study in the Yunnuk area and along Noru Dere about $2 \mathrm{~km}$ northeast of Daril show that limestone-serpentinite contacts are sharp but irregular and that attitudes range from horizontal to nearly vertical. Although limestone is locally fractured and contorted, it shows no evidence of silicification, nor other indications of metasomatism or contact metamorphism.

Between Yunnuk and Blyikboğazı, notably on the western slopes above Yunnuk Dere, highly contorted and fractured limestone of Karapinar Dere overlies partly silicified serpentinite along irregular, undulating, generally abrupt contacts. Erosion of limestone overlying serpentinite has produced highly irregular lobate contacts north and east of the peak of Zülfükaroğluçalı Tepe. Effects of contact metamorphism are lacking.

Fault contacts equivalent to cold-intrusive contacts, which cannot be sharply distinguished from the possible erosional category, are common in the mapped area; they are further described in the section on structure. Such contacts, especially between serpentinite and rocks of the Inceciğin Dere sequence, are locally well exposed and are unmetamorphosed.

Jacobson and others, 1972 , p. 16) reported a well-exposed intrusive relationship between serpentinite and massive limestone of Cretaceous to Eocene age west of the Deveci mine. At this locality, according to Jacobson, "serpentinized rocks and limestone interfinger and locally have a gradational metamorphosed contact zone." No comparable intrusive relationship was found in quadrangle K39- $\mathrm{a}_{1}$ and K39-a $\mathrm{a}_{2}$. Jacobson and others (1972, p. 34) suppose, moreover, that the siderite deposits of the Devici mine have originated from hydrothermal solutions emanating from the ultramafic rocks during emplacement of the latter but are unable to cite specific evidence for such genesis.

Tectonic relationships and age.-The serpentinite-gabbro complex in the Kuluncak-Sofular area, like most other such complexes in Turkey, is of the Alpine type (Thayer, 1960). Such complexes commonly give evidence of having been intruded cold and essentially solid, or possibly as crystal mushes with cool borders (Thayer, 1960, p. 257) ; consequently, they produce negligible contact metamorphism. This has been documented for the area under discussion, and it is also true for most, if not all, other Turkish complexes (Brinkmann, 1968, p. 116-117). 
Masses of serpentinite and gabbro, generally overlain by oceanic basalt and deep-sea sediments (ophiolites), have been the subject of much speculation and discussion (summarized by Dewey and Bird, 1971, p. 3180-3181; and Coleman, 1971, p. 1212-1215). The prevailing view of the origin of ophiolite complexes is that they represent slices of oceanic crust or upper mantle in zones of subduction or obduction (Coleman, 1971) at oceanic-continental plate margins. This concept is almost certainly relevant to some of the major Turkish ophiolite belts, such as those near the North Anatolia fault and in southeastern Turkey (Brinkman, 1968, figs. 4 and 5), which coincide at least in part with the inferred position of plate margins (McKenzie, 1970, p. 242, fig. 4). Whether this concept can be meaningfully applied to the Kuluncak area, which is on a relatively stable part of the Anatolian Plateau at some distance from active orogenic zones, is debatable. Nevertheless, modern ideas of crustal evolution must be increasingly kept in mind during future geological investigations in Turkey, whether they be detailed or regional in scope.

A basic question regarding the serpentinite complexes of Turkey is the time of their initial emplacement. Field relations suggest that such emplacement took place mostly during the Late Jurassic and Cretaceous, in any case during the Mesozoic (Blumenthal, see section "Unpublished reports"; Wijkerslooth, 1941a, 1942; Nebert, 1959b; Petrascheck, 1958; Brinkmann, 1968) ; the possibility of a Paleozoic age for some of the complexes has also been considered (Wijkerslooth, 1941b; Kaaden, 1959). Wijkerslooth (1941a) established an age of initial intrusion of late Jurassic to Early Cretaceous for serpentinite bodies near Divriği, about $70 \mathrm{~km}$ northeast of Kuluncak. Izdar (1963) concluded that the serpentinite in the Hekimhan area and in the Kuluncak area (Idzar, see section "Unpublished reports") must be older than Campanian, inasmuch as Campanian sediments (Tohma Group of this report) were deposited on it; he assumed the time of initial intrusion to be middle Cretaceous. This study has confirmed the first part of Izdar's conclusion, but no evidence was recognized to establish the time of initial emplacement. An attempt to date gabbro associated with serpentinite by the $\mathrm{K}-\mathrm{Ar}$ method proved inconclusive (Leo and others, 1974). On the other hand, the faulted (cold intrusive) contacts between serpentinite and overlying rocks as young as middle to late Eocene indicate that tectonic remobilization of serpentinite continued throughout much of the Tertiary.

The sequence of events involving the serpentinite-gabbro complex the Kuluncak-Sofular area can be summarized as follows: 
1. Existence of an eroded upper surface of ultramafic and mafic rocks during early Late Cretaceous time; formation of some siliceous crust on serpentinite;

2. Uplift and further erosion to furnish material for the Tökler Formation;

3. Transgression by Late Cretaceous seas and deposition of limestone (limestone of Karapınar Dere) onto serpentinite, probably followed by

Intrusion of limestone of Karapinar Dere by serpentinite;

4. Uplift of serpentinite in response to tectonic stress, resulting in further uplift and deformation of the same limestone, and furnishing a source of ultramafic and mafic rocks for the Eocene conglomerates (sedimentary sequence of Inceciğin Dere) ; major period of formation of silica-carbonate crust;

5. Deposition of Inceciğin Dere sequence, partly upon silicified serpentinite;

6. Renewed uplift and tectonic squeezing of serpentinite to invade and deform the Eocene rocks.

\section{CRETACEOUS}

ALKALIC DIABASE

Nature and distribution.-Plugs and tabular bodies of diabase are widely distributed within the Tohma Group and are found almost nowhere else. The tabular diabase bodies, which are interlayered with tuff and sandstone mainly in the area between Hafhaf Tepe and the western edge of the mapped area, are as much as $40 \mathrm{~m}$ thick and $1-2 \mathrm{~km}$ in lateral extent. They consist of dark, even-grained, nonvesicular rock, are typically altered, and few show chilled margins. Most appear to be sills but some may be flows. Isolated diabase dikes cut serpentinite north of the Yunnuk fault (1.5 km east of Orthapınar Mezraası) and west of Köydere $(0.5 \mathrm{~km}$ south of Köyderesi village $)$. Diabase plugs are found at the end of the east-northeast-trending ridge $1 \mathrm{~km}$ north-northeast of Yünlüce, at Kale Mevkii about $2 \mathrm{~km}$ eastsoutheast of Bicir village, and possibly elsewhere. Almost flatlying diabase overlain by welded tuff surrounds Dereköy village near the eastern edge of K39-a $\mathrm{a}_{2}$. As noted earlier, basalt or finegrained diabase, in part showing pillow structure, crops out east of Yanıkharman Tepe and Ciğdemli Tepe and continues eastward

3 The term alkalic diabase is used because of the relatively high alkali content, especially $\mathrm{K}_{2} \mathrm{O}$ (table 1 , analyses $5-8$ ). 
into $\mathrm{K} 39-\mathrm{b}_{1}$; because they are almost certainly flows, the latter rocks are included with the Sofular Formation.

The generally close association of diabase with the Sofular Formation, which rests unconformably on the serpentinite basement and which may be significantly younger, is a reason not to consider this diabase as an integral part of an ophiolite complex (as presently defined, Penrose Field Conference, 1972). Another reason is the distinct compositional differences between the diabase and the gabbro associated with serpentinite (figs. 1-3). The individual diabase bodies were not mapped in detail, and most of them are shown somewhat schematically on plate 1 .

Petrographic and chemical features.-The alkalic diabase is typically a dark-brown to black fine-grained rock that shows some megascopic evidence of alteration. Microscopic examination shows a normal diabasic texture consisting of a web of plagioclase laths and scattered small plagioclase phenocrysts, and interstitial mafic minerals, various alteration products, and opaque material. In most rocks, plagioclase typically shows pronounced normal zoning from sodic rims (approximate range, $\mathrm{An}_{0-20}$ ) to calcic cores (normally $\mathrm{An}_{55-i 0}$, rarely $\mathrm{An}_{80-90}$ ). The sodic rims are commonly bounded sharply from the calcic cores and in places contain unidentified microinclusions. The calcic cores may show oscillatory zoning that is cut off at the boundary of the albitic rim. Less commonly, a strongly differentiated zone occurs between the cores and rims of the plagioclase crystals. In both instances, the degree of compositional variation from core to rim is excessive for plagioclase in normal diabase and may reflect replacement and (or) differentiation of original calcic plagioclase through the action of late Na-rich fluids, as in spilites.

The mafic constituents of the diabase are partly or wholly replaced, depending on the degree of alteration. In the freshest rocks, remnants of clinopyroxene are partly replaced by chlorite, carbonate, and iron oxide; in more highly altered rocks, no original mafic minerals remain. The calcic cores of plagioclase grains are locally partly replaced by actinolite, epidote, and(or) calcite. Olive-brown, apparently primary biotite is present in about half of the samples and is reflected in the high potassium content of analyzed samples. In its most highly altered condition, the diabase is a gray-green rock consisting almost entirely of chlorite, carbonate, and dusty opaque material in which original plagioclase is virtually replaced but still apparent by a relict weblike texture.

Four diabase analyses (table 1, analyses 5-8) reflect the variations of petrographic character in relatively fresh rocks. None- 
theless, the moderate water content and high $\mathrm{CO}_{2}$ content of even the freshest appearing rocks-analyses 5 and 7 -indicate that even these rocks are considerably altered, as shown microscopically by the ubiquitous carbonate and chloritic material in the groundmass.

The most notable feature of all four analyses is the high content of alkalies. The $\mathrm{Na}_{2} \mathrm{O}$ contents are slightly higher than in most diabases but too low for true spilites, although transition to spilite is suggested by the development of albitic rims on primary calcic plagioclase. The $\mathrm{K}_{2} \mathrm{O}$ content, on the other hand, is well above that of normal diabase and much higher than in usual spilites, which typically contain less than 1 percent $\mathrm{K}_{2} \mathrm{O}$. These rocks are therefore referred to as alkalic diabase rather than spilite. The relative enrichment in alkalies, particularly potassium, could have been caused by contamination by trachyte and associated rocks, either in the magma chamber or in passing through the crust to the surface.

Metasomatized mafic rocks that crop out south of Deliktaş Tepe on the eastern boundary of $\mathrm{K} 39-\mathrm{a}_{2}$ and continue intermittently eastward beyond Hasançelebi (Jacobson and others, 1972) are tentatively regarded as the equivalent of the diabase and (or) flows associated with the Sofular Formation. The metasomatic rocks are dense, gray green, and contain a complex and varied suite of mostly secondary minerals, including epidote, actinolite, marialitic scapolite, potassium feldspar, biotite, chlorite, muscovite, calcite, and opaque minerals (largely magnetite). Experiments in concentrating magnetite from these rocks (Pressler, 1971) indicate that they may constitute a promising source of iron ore.

Age.-A K-Ar age determination on plagioclase from a dike of alkalic diabase intruding the Tohma Group (69-GWL-122B; table 1, analysis 5) gave a value of $75.5 \pm 2.1 \mathrm{~m} . \mathrm{y}$. (Leo and others, 1974), indicating that the diabase was emplaced during, or immediately after, deposition of the Tohma.

\section{GRETACEOUS AND TERTIARY}

TRACHYTE AND TRACHYANDESITE

Nature and distribution.-Trachytic rocks, ${ }^{4}$ both extrusive and intrusive, are abundant in the mapped area. Trachyte and associated subordinate trachyandesite that have local tuffaceous layers form a broad northwest-trending ridge from Kırmızıçal

${ }^{4} \mathrm{As}$ trachyte, trachyandesite, and trachyte porphyry of the region are doubtless genetically related, they are in places referred to collectively as "trachytic rocks." 
Tepe $\left(\mathrm{K} 39-\mathrm{a}_{2}\right)$ beyond Boyal village $\left(\mathrm{K} 39-\mathrm{a}_{1}\right)$. Other large trachyte masses, apparently flows, are found west and southeast of Yünlüce village and at Deliktaş Tepe, northeast of Karincalık village. An intrusive trachyte plug that has well-developed vertical jointing forms a small conical hill $1.8 \mathrm{~km}$ south of Darlli village; probable plugs are found north and south of Tohma Suyu near the southwest corner of $\mathrm{K} 39-\mathrm{a}_{2}$, and a swarm of trachyte dikes trend northwest along Salloğlanın Dere. A stock of trachyte porphyry about $4 \mathrm{~km}$ long and $1 \mathrm{~km}$ wide crops out west and southwest of Arikdam1 village (western part of K39-a ${ }_{1}$ ).

The broad trachyte masses are essentially structureless, but their contacts are commonly horizontal or nearly so. Locally, as in the area around Boztepe west of Yünlüce, the relationship between trachyte and the adjacent Tökler Formation indicates that the contact changes from subhorizontal to subvertical over short distances.

These field relations suggest that the broad trachytic masses represent puylike domes intermediate between the plugs and flows that are characteristic of viscous silicic magmas.

Trachyandesite, in which part or all of the feldspar phenocrysts are sodic to intermediate plagioclase, is megascopically indistinguishable from trachyte; hence, its distribution, relative abundance, and structural relationship to the latter could not be determined. The trachyandesite may form separate flows or could represent gradations in larger plugs or domelike masses. In certain areas, such as at Demirlitaş south of Yüce Tepe, trachyandesite constitutes the lowest part of the section over the Sofular Formation, but this is not necessarily true everywhere.

Fine-grained, quartz-rich, pyroclastic-appearing rocks around Siğirkiran Tepe $2.5 \mathrm{~km}$ south of Yünlüce evidently are a tuffaceous phase of the trachyte, although no contacts between the two rock types were found.

Petrographic and chemical features.-The trachyte is typically a pink to brown, dense to slightly vuggy rock, commonly having a dark-brown weathering stain and little or no megascopic structure besides irregular fracture. Except for local biotite and ubiquitous accessory iron oxide (mostly magnetite), these rocks consist entirely of sanidine. The groundmass is made up of elongated microlites, which commonly show a fluidal texture. Phenocrysts normally constitute from about 3 to 25 percent of the rock and range in size from $1 \mathrm{~mm}$ to about $5 \mathrm{~mm}$; the trachyte porphyry west of Arlkdamı contains about 50 percent sanidine phenocrysts as much as $2 \mathrm{~cm}$ long. The phenocrysts are typically elongated prisms but 
may be stubby, rounded, or irregular because of partial resorption, and some are glomeroporphyritic. Carlsbad twinning is common in phenocrysts and microlites; cross-hatch twinning and exsolution features are absent. Biotite, when present, is olive brown and well crystallized; typically it constitutes about 2 percent, rarely as much as 5 percent, of the rock. Dusty to granular magnetite makes up an estimated 1 to 5 percent.

Trachyte porphyry at a chilled contact against Sofular Formation at Kizllburun Sirt (near western boundary of K39-a ${ }_{1}$ ) contains aegirine and minor pargasite (?), suggesting an affinity with the alkalic syenite body of Avliya Dere. A chemical analysis, however (table 1, analysis 11), shows the composition to be closer to trachyandesite and related tuffs (figs. 2, 3).

Trachyandesite of the Kuluncak-Sofular area is similar to trachyte except that a part of all the phenocrysts are sodic to intermediate plagioclase (commonly albite-oligoclase, exceptionally andesine).

Trachyte and trachyandesite both typically show minor alteration at Kizılburun Sirt (near western boundary of K39-a a $_{1}$ conterial not obviously related to any primary mineral; some rocks contain small disseminated carbonate patches evidently of secondary origin. Somewhat unexpectedly, trachyte dikes closely related to lead-zinc mineralization, for example, along Sallığlanın Dere, are not more altered than trachyte away from such areas.

Eight analyses of trachyte, trachyandesite, and related tuffs are shown in table 1 (analyses 9-13, 15-17). Analyses 9-10 and 1213 document the distinct compositional differences between trachyte and trachyandesite. These differences are not recognizable in the field, in hand specimen, or even always under the microscope (for example, microscopic examination suggests that sample 69GWL $-90 D$ (analysis 13) is a trachyte rather than a trachyandesite). Welded tuffs from the Sofular Formation (analyses 15-17) are generally similar to the associated lavas (fig. 1).

\section{ALKALIC SYENITE OF AVLIYA DERE}

Nature and distribution.-A stock of white to pale-gray medium-grained alkalic syenite is intermittently exposed between Alibeyli Tepe (northwest part of $\mathrm{K} 39-\mathrm{a}_{2}$ ) and Kaletepe (west of Şuul Dere near the northeast corner of K39-a $a_{1}$ ). Syenite outcrops trend roughly northwest for about $5 \mathrm{~km}$, and the maximum width of the outcrop area is about $2.5 \mathrm{~km}$. The stock intrudes the limestone of Karapinar Dere, and the contact, which is clearly exposed in a number of places, shows a low dip almost everywhere except 
near Kaletepe. This fact, together with evidence of recrystallization of limestone at least $500 \mathrm{~m}$ away from the southern and southwestern margin of the syenite, indicates that the stock may be considerably larger than surface exposures indicate.

The contrast between syenite and limestone, where observed, is sharp and marked by no other effects of contact metamorphism. than recrystallization of the overlying limestone to coarse marble (individual grains are 1-2 $\mathrm{cm}$ across) and the presence of local zones of garnet-bearing skarn. No evidence of metasomatism or mineralization was observed, but anomalously high values of $\mathrm{Zn}$, $\mathrm{Pb}$, and $\mathrm{Cu}$ were detected west of the syenite body ( $\mathrm{pl}$. 1, samples 30-33). This recrystallization is the only documented case of contact metamorphism in the mapped area and is in sharp contrast to the extensive zone of metasomatised mafic rocks, related to a syenite (?) intrusion that crops out mainly between the Karakuz mine and Hasançelebi in the two quadrangles to the east (Jacobson and others, 1972).

Petrographic and chemical features.-The syenite is a white to pale-gray, fine- to medium-grained rock having nearly panidiomorphic texture imparted by prismatic feldspar crystals and acicular aegirine prisms. Under the microscope, it shows broad locally perthitic plates of potassium feldspar, slender prismatic albite laths, disseminated prisms of deep-green aegirine (5-15 percent), subordinate phlogopite, and interstitial feldspathoid (less than 5 percent), which may be nepheline, analcite, or sodalite (table 1 , analysis 14 ).

This mineral paragenesis is fairly constant throughout the alkalic syenite body but is unlike that of the trachytic rocks elsewhere in the area, with the exception of the marginal phase of the plug of trachyte porphyry on Kizılburun Sirt (table 1, analysis 11 , sample $117 \mathrm{D} / 2$ ), The mineralogical similarity between these two rocks and the intermediate bulk composition of sample $117 \mathrm{D} / 2$ between trachyte (table 1 , analyses 9,10 ) and alkalic syenite (table 1, analysis 14) suggest a possible differentiation sequence from trachyte to alkalic syenite; this is supported by the relative ages of the two rock units (following section).

\section{AGE OF TRACHYTIC ROCKS AND SYENITE}

$\mathrm{K}$-Ar age determinations on two samples of trachyte (69GWL-27D-2 and 69-GWL-124A) gave results of $74.3 \pm 1.7$ m.y. and $71.1 \pm 1.6 \mathrm{~m} . \mathrm{y}$., respectively, and an age of $65.2 \pm 1.6 \mathrm{~m} . \mathrm{y}$. was obtained on alkalic syenite (sample 69-GWL-53C) (Leo and others, 1974). Thus, the trachyte is Late Cretaceous, and the age 
of the syenite marks the Cretaceous-Tertiary boundary. These determinations are in good agreement with geological observations in the region. Trachytic rocks cut the serpentinite-gabbro complex and also cut and overlie the Upper Cretaceous Sofular Formation. Trachyte fragments are found in graywacke and welded tuff of the Sofular Formation indicating that some trachyte is older than the Sofular. Also, locally, trachyte fragments are found in the Eocene sedimentary sequence of Inceciğin Dere. The chemical similarity between tuffs of the Sofular Formation and the overlying trachyandesite (table 1) suggests that the tuff marks an early stage of this trachytic volcanism.

The alkalic syenite intrudes the probable Upper Cretaceous limestone of Karapınar Dere west of Başören. In the Divriği area, much larger syenite intrusions are considered, on the basis of field relations, to be between late Late Cretaceous (Senonian) and Oligocene in age (Wijkerslooth, 1941a, p. 318).

\section{MIDDLE TO UPPER MIOCENE VOLCANIC SEQUENCE.}

Nature and distribution.-Much of the northern part of the mapped area is covered by near-horizontal to gently dipping flows of basalt and andesite and some interbedded tuff-breccia and agglomerate. The 1:500,000-scale map of Turkey (Sivas sheet) indicates that these rocks in the mapped area represent a small southwestern outlier of a much greater area of volcanic rocks approximately bounded on the northeast by the towns of Yellice, Danişment, Arapkır, and Argüvan (index, pl. 1). Izdar (1963, p. 34) referred to Yamadağ and Karasöker Dăg (index, pl. 1) as the main eruptive centers.

Petrographic and chemical features.-The volcanic rocks constitute three compositional types: (1) tholeiitic olivine-bearing basalt, (2) hypersthene-bearing andesites, including tuff-breccias, and (3) hornblende dacite. The volcanic rocks are generally fresh, but they are not particularly well exposed. They were not mapped in detail, but the main outcrop areas of the various compositional types are shown on plate 1.

Olivine basalt crops out in small outliers south of the larger northern outcrop area and locally within the large area, $1.5 \mathrm{~km}$ east of Başören village (pl. 1). It is typically a very fresh, darkgray to black vesicular holocrystalline rock containing faintly violet augite, and olivine partly replaced by iddingsite; the two minerals together constitute between 10 and 15 percent of the rock. Plagioclase shows moderate to strong normal zoning, as much as $\mathrm{An}_{32-67}$. The normative plagioclase composition, however, 
is $\mathrm{An}_{45}$ (table 1, analysis 18 ), reflecting the comparatively high $\mathrm{Na}_{2} \mathrm{O}$ content.

Andesite of group 2 constitutes the main outcropping rock. All andesite contains faintly pleochroic hypersthene and also contains deep red-brown hornblende and (or) faintly violet augite. The relative proportions of the mafic minerals show significant and seemingly random variations over short distances, but these variations seem to have little effect on bulk composition (table 1, analyses 1921). The plagioclase in these rocks is typically zoned between $\mathrm{An}_{40}$ and $\mathrm{An}_{65}$; hence, the average plagioclase composition appears to be sodic labradorite, but the normative plagioclase composition is in the andesine range.

Hornblende dacite, a rock conspicuous by its light-gray to brownish-red color, was found only on the summit and north flank of Ağcahüyük Tepe. A chemical analysis (table 1, analysis $22)$ shows that this rock is distinctly more silicic than the rocks of group 2.

Throughout the northern outcrop area, andesite is locally interlayered with thick beds or lenses of tuff-breccia grading to agglomerate. A gradational sequence of these rocks is well shown along the valley of Deregözü Dere westward from Germeç Tepe. On the south flank of Germeç Tepe, andesite overlies a massive bed of light-gray tuff-breccia some $50 \mathrm{~m}$ thick. This rock has a glassy porous matrix containing fragments of pumice and andesite as much as $1 \mathrm{~cm}$ across; it also contains crystals of plagioclase, hypersthene, augite, and hornblende in approximately the same proportions as the associated lavas (see table 1). Within $1 \mathrm{~km}$ northwest, near Yaylaevleri, the tuff-breccia grades to agglomerate that contains andesite blocks a few centimeters to $2 \mathrm{~m}$ across. These blocks are similar to the andesite lava.

Similar sheets, or discontinuous lenses, of tuff-breccia or agglomerate, are interbedded with lava flows elsewhere within the northern outcrop area; only the most continuous outcrops, near Germeç Tepe, have been distinguished on plate 1.

Compositions of basalt and andesite (table 1, analyses 18-21) indicate a somewhat alkaline trend for these rocks as well. The basalt (analysis 18) is close to average alkalic basalt (Manson, 1967 , p. 225, table 5). Two mineralogically distinct andesites (analyses 19-20) and andesitic tuff-breccia (analysis 21) show fairly similar bulk compositions, but in all three of these analyses, $\mathrm{K}_{2} \mathrm{O}$ is distinctly high for rocks of andesitic composition (fig. 2). The source of the $\mathrm{K}_{2} \mathrm{O}$ is not obvious in any of these rocks (including the basalt), and much of it may be occult in the groundmass. 
No excessive $\mathrm{K}_{2} \mathrm{O}$ is evident in the dacite from Ağcahüyük Tepe (analysis 22), and the analysis is normal in other respects, which suggests that this isolated, and somewhat younger, dacite plug was not subject to the same contamination that affected most of the post-Eocene volcanic rocks.

Age.-The volcanic rocks overlie older formations including the limestone of Karapınar Dere, trachyte-trachyandesite, and the sedimentary sequence of Inceciğin Dere; the dacite plug of Ağcahüyük Tepe appears to cut the limestone of Yapalaklı Tepe. Andesites are overlain by the limestone of Yapalakl Tepe and also by the dolomite of özbek.

Two samples of andesite from the southwest side of Germeç Tepe (table 1, analysis 19-20) gave K-Ar ages of $18.7 \pm 0.5$ m.y. and 17.6 \pm 0.5 m.y.; basalt from $1.3 \mathrm{~km}$ east of Başören village (table 1, analysis 18) gave $16.8 \pm 0.5$ m.y.; and dacite from Ağcahüyük Tepe (table 1, analysis 22 ) gave $14.1 \pm 0.4$ m.y. These middle to late Miocene ages are in good accord with field relations. They also show that the limestone of Yapalakl Tepe is late Miocene in age, whereas the dolomite of özbek could be younger than Miocene.

COMPOSITIONAL AND AGE RELATIONSHIPS OF THE IGNEOUS ROCKS

Compositional relationships between the igneous rocks of the Kuluncak-Sofular area are shown in figures 1, 2, and 3. Figure 1 shows the overall range of compositions in terms of total alkalies. Figure 2 emphasizes the spread in the $\mathrm{Or} / \mathrm{Ab}$ ratio among the Upper Cretaceous and lower Tertiary volcanic rocks and also points up the generally alkalic character of these rocks. The dashed line connecting Nockolds' average compositions (1954), regarded here as a kind of stylized calc-alkaline differentiation trend, serves to show how far most of the post-Campanian rocks depart from such a trend. Especially striking is the contrast between the notably alkali-poor pre-Campanian gabbro and the alkali-rich upper Campanian diabase. This is an additional reason for not regarding the diabase as an integral part of an ophiolite sequence, but rather to consider it as marking the beginning of Late Cretaceous alkalic volcanism.

Figure 2 also indicates a distinct departure of the Miocene volcanic rocks from the generalized differentiation trend; this, however, is not seen in figure 3 , where the same rocks define a fairly straight-line trend ranging from slightly undersaturated to oversaturated. The bulk of Upper Cretaceous volcanic rocks still show up in figure 3 on the undersaturated side of the calc-alkaline trend. 


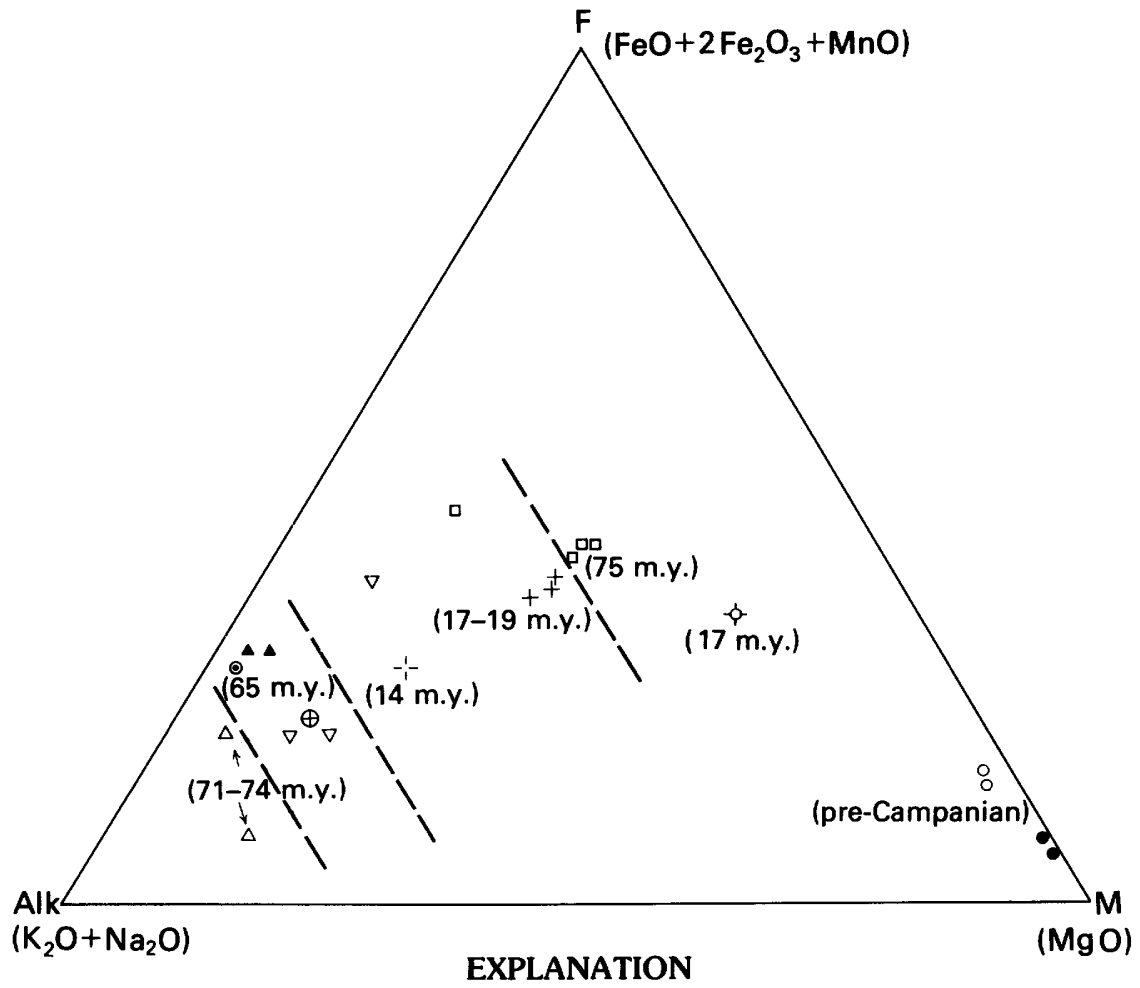

- serpentinite (table 1, analysis 1-2)

- gabbro (analysis 3-4)

- alkalic diabase (analysis 5-8)

$\Delta$ trachyte (analysis 9-10)

$\oplus$ marginal phase of trachyte porphyry (analysis 11)

- trachyandesite (analysis 12-13)

- alkalic syenite (analysis 14)

$\nabla$ Sofular welded tuffs (analysis 15-17)

$\rightarrow-$ olivine basalt (analysis 18)

+ andesite and andesite tuff-breccia

- (analysis 19-21)

$\therefore-$ hornblende dacite (analysis 22)

FigURE 1.-F-M-Alk diagram of igneous rocks of the Kuluncak-Sofular area. Dashed lines are arbitrarily placed but are parallel to the M-F boundary. Numbers in parentheses represent radiometric ages (see text).

Available radiometric ages were plotted in figure 1 to show trends of chemical evolution, if any, over time. No straightforward trends are apparent either in the Upper Cretaceous or in the Miocene sequence, although further refinement of chemical 


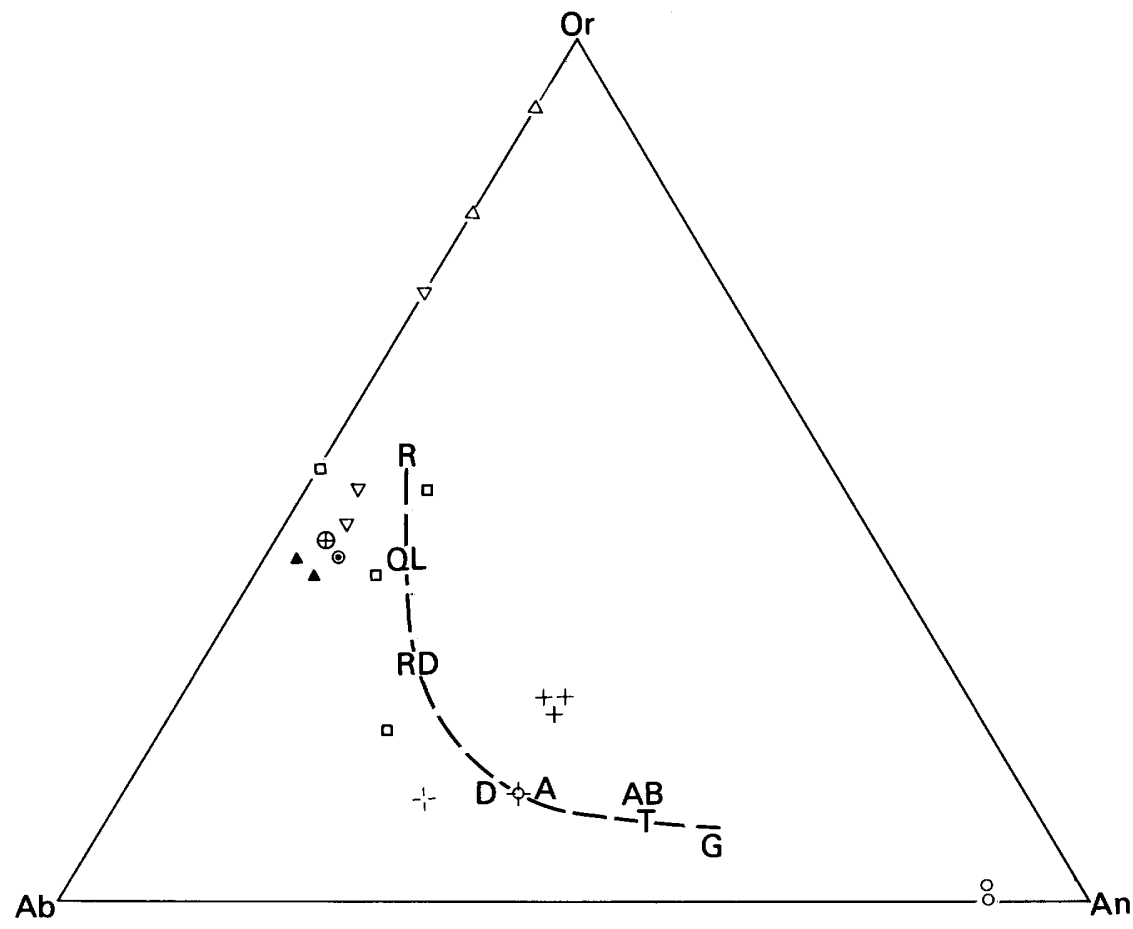

EXPLANATION

\author{
$R$, rhyolite \\ QL, quartz latite (dellenite) \\ $\mathrm{RD}$, rhyodacite \\ $D$, dacite \\ $A$, andesite \\ $T$, tholeiitic basalt \\ $A B$, alkaline basalt \\ G, gabbro
}

Figure 2.-Or-Ab-An diagram. Symbols for Kuluncak-Sofular rocks are shown in figure 1 (serpentinite points not shown). Letters are Nockolds' average compositions (1954). Dashed line is fictitious differentiation trend based on average compositions.

and radiometric data (or, possibly, a different form of presentation) might reveal such trends. A progressive shift from potash-rich trachyte to soda-rich syenite over the interval 74 m.y.65 m.y. is suggested by associated rocks of intermediate composition (analysis 11-13 and 15-17, table 1). The relation of age to composition in the Miocene volcanic rocks suggests that dacite may have differentiated from andesite but that basalt represents a distinct magma. 


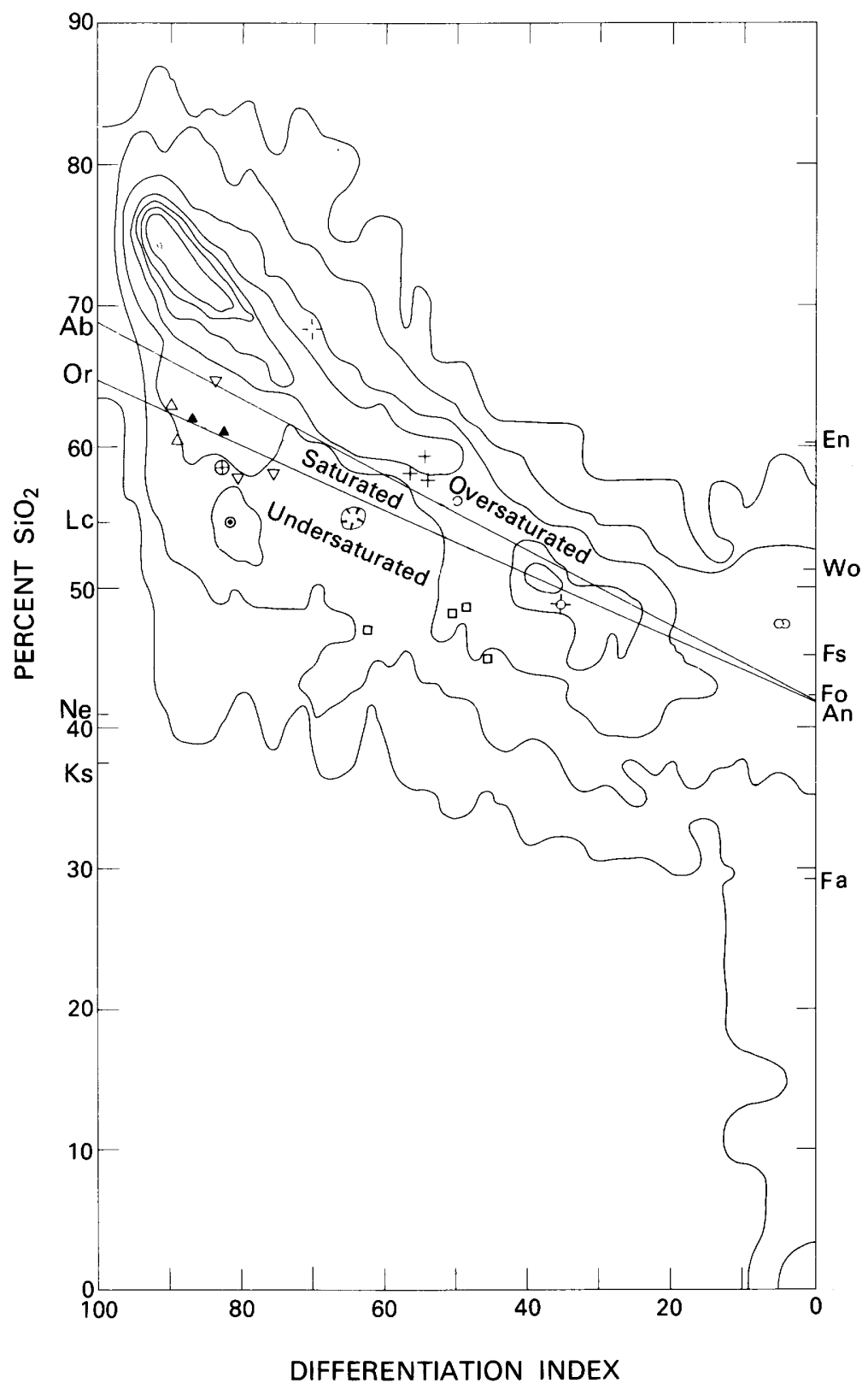

FigURE 3.-Contoured silica-differentiation index diagram (after Thornton and Tuttle, 1960). Contours relate to frequency distribution of 5,000 analyses in Washington's tables. Differentiation index is defined as the sum of normative $\mathrm{Q}+\mathrm{Or}+\mathrm{Ab}+\mathrm{Ne}+\mathrm{Lc}+\mathrm{Ks}$. Kuluncak-Sofular notations as in figures 1 and 2 (serpentinite points not shown). 


\section{STRUCTURE}

The dominant structural trend in the Kuluncak-Sofular area is northwest. This trend is particularly evident southwest of the Yunnuk-Düşüksögüt fault system, where lower Tertiary and Upper Cretaceous rocks rest in a faulted homocline upon the serpentinite basement. Northeast of the Yunnuk-Düşüksöğüt fault system, structures are less regular and (or) less well defined owing to lack of bedding and generally poor exposures. Faults, fractures, and folds throughout the area, but especially around Yunnuk, appear to be mostly related to intermittent movement within the serpentinite basement from middle Cretaceous to middle Tertiary and perhaps even later.

\section{FAULTS}

\section{YUNNUK-DÜŞÜKSÖĞÜT FAULT SYSTEM}

A major fault in the area extends from east of Inceciğin Tepe northwestward beyond Darll Dere, where it disappears beneath post-Eocene volcanic rocks underlying Karaçal Başı Tepe; its exposed length is about $12 \mathrm{~km}$. Between Saylak Tepe and Düşüksöğüt Tepe, the fault is difficult to trace, and its continuation is inferred. Southeast of the Ortapinar Mezraasi area, the fault is referred to as "Yunnuk fault," and northwest of there as "Düşüksögüt fault." The entire fault and its branches are together designated on the "Yunnuk-Düşüksögüt fault system." Major subsidiary faults have been given informal names (Bıyıkboğazı fault, Karatepe-Döllükgüney Tepe fault, Kırazlıkoyak fault, Kadirkoyaği fault) for convenience.

Yunnuk fault.-The Yunnuk fault is the most prominent of the many fault in the area between Ortapinar Mezraasi, Kuluncak, and Bıylkbogazı. Structural relationships in this area are most easily explained by vertical-differential movement of fault blocks with respect to each other; but the blocks as a whole have moved relatively upward. The apparent displacement on most of the faults is not more than a few tens of meters, and the maximum aggregate displacement may amount to a few hundred meters.

The Yunnuk fault is well exposed along the northeastern front of Incegiğin Tepe, where it has brought the middle unit of the Incecigin Dere sequence against the upper unit. Northwest of Inceciğin Dere, movement on both the Yunnuk and the Bryskboğazi faults have brought ultramafic rocks and overlying limestone of Karapinar Dere upward. On Saylak Tepe, the Yunnuk fault is marked by a breccia zone within the Inceciğin Dere lime- 
stone unit, and a short distance northwest, the fault apparently dies out.

The Karatepe-Döllükgüney Tepe fault likewise appears to bring the Inceciğin Dere limestone unit upward on the northwest. East of Kuluncak, an abrupt lithologic and topographic break along the same fault between serpentinite and Inceciğin Dere sandstoneconglomerate provides a good example of Tertiary (post-Eocene) movement of serpentinite. Another such example is provided by the Kirazlıkoyak fault in Kirazlllkoyak Dere about $500 \mathrm{~m}$ southeast of Köyderesi village, where slickensided serpentinite is brought against fractured but unsilicified limestone along a subvertical contact.

The northeast-trending Kadırkoyağı fault offsets upper Tertiary conglomerate northwest of Payaml Tepe and east of Yunnuk; the same is true of the north-trending Biylkbogazı fault, a small northeast-trending fault southeast of Dereköy, and the inferred fault north of Tepebaşı Tepe. A northeast-trending branch of the Blylkbogazı fault appears to cut Miocene volcanic rocks and limestone of Yapalakli Tepe. All the faults are younger than the Yunnuk-Düşüksöğüt fault, which is covered by the Miocene volcanic rocks. Hence, there is a possible connection between direction and age of faulting, but information is insufficient to discern a general pattern.

Most of the remaining faults and fractures in the intensely disturbed area around Yunnuk are shown somewhat schematically on plate 1 owing to poor exposures caused by soil cover, slumping, and many landslides.

Düşüksöğ üt fault.-The Düşüksöğüt fault brings serpentinite on the southwest against limestone of Karapinar Dere on the northeast. The fault is well exposed near Noru Dere and northeast of Kizilok Boynu Tepe. Field relations indicate that the northeastern side moved relatively downward, but the amount of displacement is unknown.

The southwestern margin of the Düşüksöğüt Tepe-Gökçegedik Tepe serpentinite belt may be a branch of the Düşüksöğüt fault that continues into Bağderesi northwest of Darılı. Additional faults cut the Inceciğin Dere sequence between Darll and Germeç Tepe. In this area, too, fracturing is intense, and the faults are shown somewhat schematically.

FAULTS IN THE KÖRMUSTAFALAR AREA

Faults of possibly large displacement bring the Tökler Formation against serpentine in the vicinity of Körmustafalar village 
(western part of K39-a $\mathrm{a}_{1}$ ). The faults strike west-northwest, subparallel to the strike of the bedding, whereas the dips appear to be subvertical or steeply northeast (see pl. 1, section $A-A^{\prime}$ ). Hence, these faults are high-angle reverse faults, almost bedding-plane faults, and their apparent displacement is of the order of a few hundred meters to many hundreds of meters. Normal faulting of such magnitude seems extraordinary, particularly so in view of the seemingly short length of the faults, and the fact that conglomerate beds near the faults are not noticeably disturbed. If the faulting preceded tilting of the serpentinite basement from its original subhorizontal position during deposition of the conglomerate of the Tökler Formation, the faults could be interpreted as thrusts that were subsequently tilted. Such an interpretation, however, presents the same difficulties as the first one. No satisfactory answer can be offered on the basis of available data.

The fault in the southwestern corner of K39-a the limestone of Chakşan Tepe against serpentinite, must also be a major fault and is apparently of the same type as those near Körmustafalar.

An inferred fault trending along Çayderesi appears to branch about $2 \mathrm{~km}$ south of Bicir, raising serpentinite north of the branch and interrupting the continuity of the Tökler Formation in this area.

\section{FAULTS IN THE GALTEPE-ZIYARETCALI TEPE AREA}

The limestone block here referred to as "limestone of Chaltepe" is partly bounded by subvertical faults which have raised it relative to the surrounding sedimentary rocks of the Inceciğin Dere sequence. The faults along the northern and northwestern boundaries form prominent scarps. The bounding fault on the south is marked by abrupt termination of the limestone of Çaltepe in a straight line, as well as by silicification and iron staining. This fault appears to die out about $600 \mathrm{~m}$ northeast of Konaktepe village, but its continuation through the village is inferred, mostly on the basis of divergent attitudes on the two sides of the fault. Much of the western contact of the limestone block is covered by alluvium; hence, the extent of faulting along the western margin could not be determined.

Several straight major gullies within the Çaltepe-Ziyaretçalı Tepe block are interpreted as fractures that possibly are related to uplift of the block along the bounding faults. 


\section{FOLDS}

Aside from regional tilting and local folding, which have been described elsewhere, few major folds were observed within the mapped area. As mentioned previously, the Upper Cretaceous section in the southwestern part of the area is tilted rather uniformly into a homocline with a northwest strike and northeast dip; these attitudes persist in the Eocene rocks of the Inceciğin Dere sequence in the vicinity of Karlik and continue intermittently as far as Yunnuk. Rocks of the Inceciğin Dere sequence in the southeastern corner of the area show a variety of attitudes, and no consistent pattern of folding can be detected. However, the beds rather consistently dip away from adjacent high areas partly underlain by serpentinite, presumably because of intermittent uplift of such areas, as discussed earlier. In the northeastern corner of the map area, the general easterly strike and northerly dips of beds of the Inceciğin sequence seem to reflect the same homoclinal trend of the formations to the southwest.

\section{ECONOMIC GEOLOGY}

Minor deposits of iron, lead, zinc, copper, and chromite, some of them known for many years, are found in the Kuluncak-Sofular area. In most places, geologic relationships do not hold out promise for larger concealed deposits. Geochemical and magnetic anomalies in certain areas, however, warrant further investigation.

\section{IRON PROSPECTS}

Geologic relationships.-Iron mineralization in the KuluncakSofular area appears to be confined to small surficial concentrations of iron oxide, mostly magnetite, but also hematite and limonite, that have formed in the weathered and silicified crust over the serpentinite-gabbro complex. Typically, the iron oxides are disseminated in the silica-carbonate rock, but locally they form small pods, lenses, veins, and fracture fillings.

This interpretation of the iron mineralization differs from those of previous workers in the area (see section "Unpublished reports" for works of Izdar, Ayan, and Ilker) who considered the iron deposits to be of metasomatic or hydrothermal origin, related to the replacement of limestone during intrusion of mafic and ultramafic rocks.

Magnetometer surveys.-An airborne-magnetometer survey of three selected areas in western, central, and eastern Anatolia was 
made by Canadian Aeroservice, Ltd., in 1960-62. Geological reconnaissance and interpretation of aerial anomalies near Kuluncak were done by $\mathrm{K}$. H. Rupprecht, G. van der Kaaden, and H. van der Meer Mohr (unpub. data, MTA, 1960-62). Ground magnetometer surveys near Düşüksöğüt Tepe, Çaşak Tepe, Kırmızıçal Tepe, and Göksivri Tepe (pl. 2A) were made in 1962 by F. Özelçi and A. Açar of MTA.

Ground-magnetometer surveys were continued during the 1969 season by Erdoğan Șengeç and other MTA personnel. The choice of areas for additional surveys (pl. $2 A$ ) was based partly on the aeromagnetic anomalies and partly on geologic considerations. The surveys, made partly with a McPhar M700 fluxgate magnetometer and partly with an Askania Gfz torsion magnetometer, were spaced on grids of 50 by $100 \mathrm{~m}$ and 40 by $30 \mathrm{~m}$.

The results of the ground magnetometer surveys coincide in a general way with the aeromagnetic anomalies but do not show continuous magnetic highs; instead, they reveal small scattered anomalies having a maximum of about $(+) 42,000$ gammas and a minimum of $(-) 30,000$ gammas, but more commonly in the $(+) 5000$ to $(+) 20,000$ gamma range (pl. $2 A$ ). Background values over serpentinite or siliceous cap rock range from $(+) 500$ to $(+) 1,500$ gammas. In some places, magnetic highs correspond to visible magnetite outcrops. In general, the ground magnetometer surveys bear out the concept of small scattered near-surface deposits in the silicified caprock, and to a large extent they are caused by disseminated magnetite. Negative anomalies cannot be attributed to magnetite but may represent inverted remnent magnetization possibly associated with ilmenite or other Ti-oxide (Isidore Zietz, oral commun., 1974).

In the following discussion, designations of areas A-I correspond to the areas of ground magnetometer surveys shown in plate $2 A$, and the larger iron oxide outcrops, some outside these areas, are designated Fe 1-6 (pls. 1 and 2A). Anomalies within the surveyed areas on plate $2 A$ are shown somewhat schematically, and only if the magnitude is greater than \pm 5000 gammas. The more detailed pattern of anomalies in two selected areas is shown at a larger scale on plates $2 B$ and $2 C$.

Area $A, F e$ 1: Kuluncak-Kara Tepe.-Several veins or fracture fillings of magnetite crop out on the northwest slope of Karatepe just above Kuluncak (N. $80^{\circ} \mathrm{E}$. from the elementary school at an altitude of about 1,300-1,360 m). The largest magnetite body, located highest on the slope, is a lens that strikes north, dips about $60^{\circ} \mathrm{E}$., and has an estimated maximum width of $5 \mathrm{~m}$ and length of 
$30 \mathrm{~m}$. Discontinuous veins or lenses of magnetite, possibly displaced by faults, continue west-southwest from this location. The westernmost body, at about $1,300 \mathrm{~m}$ altitude, is about $20 \mathrm{~m}$ long and $2-3 \mathrm{~m}$ wide. These are the largest magnetite exposures found in the entire map area. The magnetite is rather sharply bounded against the wall rock and has a narrow transitional zone of thin stringers and disseminated magnetite. Assuming that the lenses extend $20 \mathrm{~m}$ below the surface, the entire deposit is estimated at 10,000-15,000 metric tonsi of magnetite.

Area B, Fe 2: Kuluncak-Göksivri Tepe.-This is essentially the continuation of Area $A$ and contains small lenses and veins of magnetite in serpentinite and overlying silicified cap rock. A ground magnetometer survey made in 1962 by F. Özelçi shows a northeast-trending line of anomalies with a maximum of about (+) 8,000 gammas. One of the largest magnetite outcrops in this area is on the north side of the Kuluncak-Sofular road (not shown on pl. 2A), $1 \mathrm{~km}$ southwest of Kuluncak, where discontinuous northeast-striking lenses are in a zone some $3 \mathrm{~m}$ wide. This exposure coincides with one of the magnetic anomalies and shows the same general trend.

Area $\mathrm{C}, \mathrm{Fe}$ 3: Yunnuk area.-Magnetite veins and pods in silicified serpentinite crop out intermittently along a small steep westtrending ridge about $500 \mathrm{~m}$ northeast of Yunnuk village. Directly above a water mill on a sharp bend in Yunnuk Dere, fracture fillings of magnetite strike N. $45^{\circ} \mathrm{W}$. and dip southwest. Farther east along the south slope of the ridge is an irregular vein or fracture filling 1-2 $\mathrm{m}$ wide and more than $50 \mathrm{~m}$ long that strikes approximately east; pods of magnetite also are exposed on the same ridge just west of the Yunnuk fault. This exposure suggests possible fault control of mineralization, but little evidence of such control was found anywhere else. Magnetic anomalies of small lateral extent and having a maximum intensity of about (+)18,500 gammas were found mainly on the south slope of the ridge; some of these anomalies coincide with magnetite outcrops. A maximum of 10,000 metric tons of magnetite may be present on this ridge.

Area D, Fe 4A-B: South slope of Zülfükaroğlu Çalı Tepe.-One $\mathrm{km}$ north of Yunnuk, magnetite crops out in a dry valley trending slightly east of south from the summit of Zülfükaroğlu Çalı Tepe. The principal exposure ( $\mathrm{Fe} 4 \mathrm{~A})$ is a zone of intermittent subparallel veins or fracture fillings of magnetite totaling about $3 \mathrm{~m}$ wide that strikes $\mathrm{N} .55^{\circ} \mathrm{W}$. and dips steeply northeast. At this location, the magnetometer registered about $(+) 8,500$ gammas (pl. $2 A$ ). This location is in poorly exposed, highly calcareous (dominantly' 
calcite) crust over serpentinite(?) that has abundant carbonate veins as much as $1 \mathrm{~m}$ wide. Boulders of magnetite-hematite (partly nonmagnetic) are locally abundant in this general area. Abundant iron oxide float covers about $100 \mathrm{~m}^{2} 250 \mathrm{~m}$ southwest of the summit of Zülfükaroğluçalı Tepe (Fe 4B).

The cluster of magnetic anomalies centered about $500 \mathrm{~m}$ southsouthwest of Zülfükaroğluçalı Tepe is marked only by minor and localized iron oxide outcrops.

To check the possibility of mineralization related to the Yunnuk fault, a magnetometer reconnaissance was done along a northwest-trending strip (not shown on pl. $2 A$ ) about $500 \mathrm{~m}$ wide just northeast of Erzincan Dere between the southwest boundary of area D and Saylak Tepe. No significant anomalies were found.

Area $E^{\prime \prime}$, Fe 5: Köçek Tepe-Düşüksöğüt Tepe-Kızılok Boynu Tepe.-A long northwest-trending belt between Köçek Tepe and Kizilok Boynu Tepe was surveyed in order to check out the main northwest-trending aeromagnetic anomaly in the area (pl. $2 A$ ). The major geologic feature along this belt is the contact between silicified serpentinite and the limestone of Karapinar Dere. The northwestern part of this contact is the Düşüksögüt fault. In the Kizılkaya ("red rock") area and on Kizılok Boynu Tepe, the serpentinite is covered by thick siliceous crust. A detailed anomaly map of Kizlok Boynu Tepe and surroundings (area $\mathrm{E}^{\prime}, \mathrm{pl} .2 A$ ) is shown on plate $2 C$. Inspection of outcrops at several of the anomalous sites shows that the siliceous cap rock is slightly magnetic owing to disseminated magnetite; also, there are sporadic magnetite pods and fracture fillings, magnetite blocks in the rubble, and abundant magnetite in the soil. Together, these features are probably sufficient to explain the moderate anomalies along this belt.

An older survey over Çaşak Tepe (area $\mathrm{E}^{\prime \prime}, \mathrm{pl}, 2 A$ ) south of Kızılok Boynu Tepe showed no anomalies greater than $(+) 1,500$ gammas. Three hundred $m$ northwest of Çaşak Tepe, a northeasttrending zone ( $\mathrm{Fe} \mathrm{5}$ ) about $100 \mathrm{~m}$ long and $20 \mathrm{~m}$ wide is marked by powdery hematite and limonite in locally silicified serpentinite.

Area F: Köçek Tepe south.-This area, centered about $1.2 \mathrm{~km}$ south of Köçek Tepe, is near the center of one of the largest aeromagnetic anomalies. The underlying rocks are silicified serpentinite covered by a thin veneer of alluvium, conglomerate with associated travertine, and trachyte. Iron oxide outcrops were not observed; the largest recorded magnetic anomaly is $(+) 2,600$ gammas. 
The larger area in the same region (Area $\mathrm{F}^{\prime}$ ), surveyed in 1962 , also reveals no magnetic anomalies greater than about $(+) 2,000$ gammas.

Area G: Sarımağara Tepe.-This area is entirely in serpentinite under thin to thick siliceous cap rock. A few small scattered anomalies were found, one of which, $160 \mathrm{~m}$ southeast of the summit of Sarımağara Tepe, has a value of $(+) 30,000$ gammas.

Area H: Caltepe-Ziyaretçal Tepe.-A small hill in the broad saddle between Çaltepe and Ziyaretçali Tepe consists of siliceous and locally ferruginous rock ("si" on pl. 1) that is clearly derived from the limestone of Çaltepe. Development of iron oxide is mainly confined to deep staining of the siliceous rocks by limonite and hematite (?) ; no magnetite was observed, and a reconnaissance ground magnetometer traverse showed no anomalies.

The observed silicification and iron stain could be related to west-northwest-trending fractures north and south of the location, although other comparable fractures on the southwest slope of Caltepe show no related silicification.

Area I: Konaktepe northeast.-A similar silicified and ferruginous zone extends about $1 \mathrm{~km}$ east-northeast from Konaktepe village at the base of Caltepe along the partly(?) faulted contact between the limestone of Çaltepe and limestone of the Inceciğin Dere sedimentary sequence. A ground-magnetometer survey revealed no anomalies.

Fe 6: Polatciğın Dere.-A small deposit of iron oxide about $30 \mathrm{~m}$ long and $3 \mathrm{~m}$ wide on Polatcigin Dere about $250 \mathrm{~m}$ north of the Kuluncak-Sofular road has formed at the contact between the serpentinite-gabbro complex to the south and trachyte to the north. As such, its presence is unique in the area. It consists mainly of porous hematite and limonite, locally containing remnants of serpentinite. The deposit does not appear to be of economic interest.

Origin of the magnetite deposits.-Because the magnetite is concentrated within and just beneath the siliceous and(or) calcareous cap rock on serpentinite, we conclude that the magnetite was formed largely if not entirely by weathering processes. This situation is highly unusual, and to our knowledge it has not been previously described in the literature. Although the serpentinite itself provides an adequate source of iron (table 1, analyses 1 and 2), Eh-pH conditions during weathering are usually incompatible with magnetite stability, which requires conditions both reducing and alkaline. Magnetite in the presence of carbonate and silica is 
stable at $\mathrm{pH}$ higher than 7 and Eh below about zero (Garrels and Christ, 1965, p. 178-229, especially figs. 7.13 and 7.22).

The required alkalinity may not constitute a problem. The $\mathrm{pH}$ of surface waters draining a serpentinite terrain was found to vary between 7.3 and 8.3 over a 20 -month period (Cleaves and others, 1974). $\mathrm{pH}$ values in excess of 10 have been measured in waters draining partly serpentinized peridotite (O. P. Bricker, oral commun., 1975). The abundant carbonate, including both calcite and dolomite, in the weathering crust in the Kuluncak-Sofular area itself suggests a pH of deposition in excess of 7.8 (Krumbein and Garrels, 1952).

The low Eh implied by the precipitation of magnetite, on the other hand, requires moderately to strongly reducing conditions that are incompatible with the present weathering environment. The potentially most effective reducing agent, a cover of organic soil, appears unlikely to have existed on the serpentinite. The topographic position of most of the magnetite on ridges or well up on slopes, moreover, effectively eliminates the likelihood of temporary bogs or swamps under which the magnetite could have formed.

The appearance of some magnetite accumulations well down in the weathering crust and partly in the underlying serpentinite (notably in areas A and B, pl. $2 A$ ) suggests the possibility that the iron was precipitated partly from confined rather than from freely circulating waters. Loss of oxygen from such waters could take place even in the absence of organic material by reaction with inorganic reducing agents, notably silicates containing ferrous iron (Garrels and Christ, 1965, p. 382). Inasmuch as the iron ultimately was precipitated in the ferrous state, however, this explanation is probably inadequate to account for the required levels of Eh. Thus, an adequate and documented explanation for these peculiar deposits cannot be offered at this time. A detailed study of this topic would provide a valuable contribution to the understanding of the range of Eh-pH conditions in nature.

A limited analogy exists between the Kuluncak-Sofular iron accumulations and residual iron oxide deposits formed by tropical weathering of serpentinite in Cuba (Spencer, 1908, 1912; Leith and Mead, 1912, 1916; Cox, 1912). The Cuban deposits, however, appear to consist dominantly of hematite and hydrated iron oxide phases and comparatively small and sparsely disseminated magnetite concentrations near the surface. Although the weathering process in the two areas is roughly comparable, the nature of the Cuban deposits (formation of bauxite, leaching of silica, and absence of carbonate) is indicative of more oxidizing and probably 
more acidic conditions than those that prevailed in the KuluncakSofular area.

Economic potential.-Observations in the Kuluncak-Sofular area indicate that the small and scattered iron oxide bodies are probably not economic. Before this conclusion is regarded as final, however, additional ground magnetometer surveys should be made around the largest anomalies to determine more precisely their shape and extent. Such surveys should be made on a grid not exceeding $10 \mathrm{~m}$ between points, perhaps $5 \mathrm{~m}$, if necessary. If one or more of the anomalies prove to be of sufficient magnitude, exploratory drilling should be considered.

\section{LEAD, ZINC, AND COPPER PROSPECTS}

Geologic relationships.-Most of the known lead-zinc mineralization is confined to contacts between trachyte dikes and serpentinite in the southwestern part of quadrangle K39- $\mathrm{a}_{2}$. The most common ore minerals are galena and sphalerite; copper sulfides are generally absent, and in the few places where copper minerals predominate they are not visibly related to such contacts. The most extensive lead-zinc mineralization is along Salloğlanın Dere, site of a small mine of Rasih ve Ihsan Maden, Ltd., ( $\mathrm{Pb}-\mathrm{Zn} \mathrm{1,} \mathrm{pl.}$ 1 , southwest corner of K39- $\mathrm{a}_{2}$ ). Here, galena-sphalerite veins that have a maximum width of $60 \mathrm{~cm}$ follow northeast-striking, steeply northwest-dipping trachyte dikes. The veins are in serpentinite at the contacts of the dikes, within the dikes themselves, and in fractures near trachyte-serpentinite contacts; some trachyte-serpentinite contacts, however, are barren. The main vein at the Rasih ve Ihsan mine has been followed to a depth of about $50 \mathrm{~m}$ from the surface, where it appears to die out. Production from the mine reportedly has averaged about 1,200 metric tons per year since 1966, but has recently been suspended.

Minor galena-sphalerite mineralization, accompanied by bleaching and white efflorescence of iron sulfate probably derived from weathering of pyrite, is found near the contacts of some trachyte dikes about $1 \mathrm{~km}$ northeast of the Rasih ve Ihsan mine. Bleaching and efflorescence are also locally found between Sallığlanın Dere and Ziyaret Dere (southeast corner of K39-a ${ }_{1}$ ).

Two $\mathrm{km}$ southwest of the Rasih ve Ihsan mine (out of the map area), northwest-striking galena-sphalerite veins as much as 90 $\mathrm{cm}$ wide are found in serpentinite away from any known trachyte contact; mining has been done here also by Rasih ve Ihsan. Similar veins are found west of Camderesi near the southern edge of 
K39- $\mathrm{a}_{1}$ in an abandoned mine of Bilfer, Sirketi, Ltd. (pl. 1, PbZn 2).

A small, worked-out lead-zinc deposit about $1.3 \mathrm{~km}$ west-southwest of Camdere Başı Tepe is in a fault zone in serpentinite $(\mathrm{Pb}$ Zn 3). Trachyte crops out a short distance to the northwest but does not appear to be involved in the faulting. Galena and sphalerite are disseminated in a brecciated zone between several northeast-striking faults having varying dips. The mineralized zone is about $20 \mathrm{~m}$ long and as much as $15 \mathrm{~m}$ wide. Several adits have been driven parallel to the faults.

Galena forms pods in silicified serpentinite about $750 \mathrm{~m}$ northeast of Yunnuk on the northwest side of Yunnuk Dere (Pb-Zn 4). The mineralization, revealed in pits dug by villagers, is very limited and almost certainly is not economic.

Geochemical prospecting and results.-Samples of stream sediment were taken along beds of both dry and running streams. Initially, samples were taken at intervals of about $1 \mathrm{~km}$ and near junctions of all significant tributaries (pl. 1). Sampling was not carried out uniformly over the entire map area but was concentrated in regions where anomalies could be expected; certain areas underlain mostly by Tertiary sedimentary rocks and upper Tertiary mafic volcanic rocks were omitted altogether. Regions where anomalies were found were resampled at closer intervals.

At each location, one sample was taken from a depth of about $10 \mathrm{~cm}$. Where silt-size sediment was present at the surface, an additional one, or sometimes two, samples were taken from the surface sediment. All samples were dried and screened through a nylon screen of about 100 mesh. Preliminary analyses of all samples were made by means of ammonium citrate extraction. Samples whose analyses exceeded $28 \mathrm{ppm}$ were reanalyzed by colorimetric determination of metal in concentration by means of dithizone, as described by Ward and others (1963, p. 27-29). Some further quantitative analyses were made of splits of selected samples by means of colorimetric methods.

Sample localities are shown on plate 1 . Actual analyses, or averages of analyses if more than 1 sample was collected, have been plotted at sample points for samples containing more than $28 \mathrm{ppm}$ metal-ion concentration, but only ranges of analyses have been plotted for samples containing less than $28 \mathrm{ppm}$ (classes are: $<2 \mathrm{ppm} ; 2-4 \mathrm{ppm} ; 4-10 \mathrm{ppm}$; and 10-28 ppm).

To test the possibility that either trachyte or serpentinite might constitute a source of base metals, some samples of these rocks 
were submitted for analysis of $\mathrm{Pb}, \mathrm{Zn}$, and $\mathrm{Cu}$ (table 2). Most of the determined quantities of these metals in both rock types are quite high, especially in the colorimetric determinations; the $\mathrm{Pb}$ content of serpentinite samples, in particular, appears extraordinarily high. Inasmuch as both $\mathrm{Pb}$ and $\mathrm{Zn}$ are below the detection limits of semiquantitative spectroscopy in two other serpentinite samples from the region (not listed in table 2), the colorimetric results for soil as well as rock samples must be regarded with some caution, pending analysis of the same (or future) samples by atomic-absorption and emission spectroscopy.

Two general areas of base-metal anomalies were identified; in order of importance they are shown as areas 1 ind 2 on plate 1 . The nature of the geochemical anomalies is summarized below. Two other areas are briefly discussed.

Area 1.-Anomalies in area 1 are high because the analyzed samples are from creeks that drain known mineralized areas. Examples are locations 1, 2, 4, 5, 8, 11, 12, 26, 27, and 28 (pl. 1). Other anomalies, such as 9, 10, 16-24, and 36, are unrelated to known mineralization, and such areas should be investigated more closely.

TABLE 2.-Lead, zinc, and copper in trachyte and ultramafic rocks, Kuluncak area

[Samples 69.GWL.90C/1, 69.GWL.90D, and 69.GWL.124A analyzed by L. Mei, U.S. Geol. Survey, by atomic-absorption spectroscopy. Remainder of samples analyzed by Solmaz Topçu, MTA, by colorimetric methods]

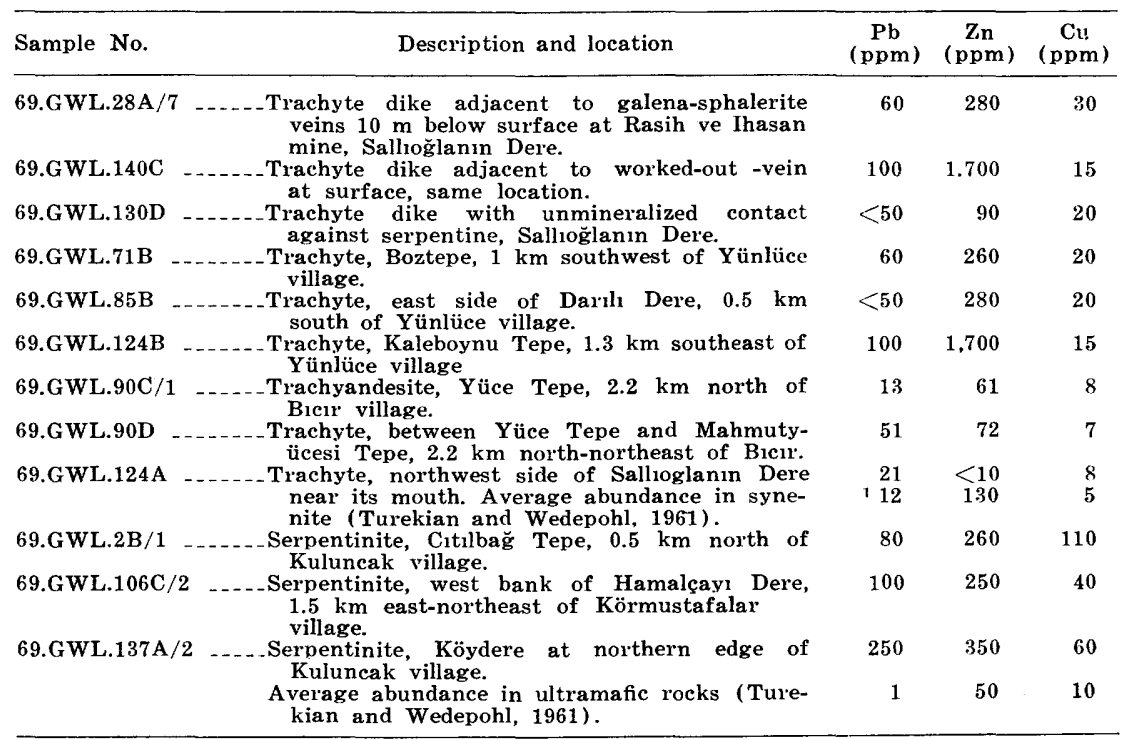

1 However, Wedepohl (1956, p. 106) reported a range of $16-43 \mathrm{ppm}$ of $\mathrm{Pb}$ for selected trachytes, and an average value of $26 \mathrm{ppm}$ of $\mathrm{Zn}$ for syenites, trachytes, and phonolites (Wedepohl, 1953, p. 118). 
The unusually high anomaly at location 9 , as well as nearby indications of hydrothermal alteration, suggest the probability of mineralization between this locality and Sallioğlanin Dere to the east. Additional samples should be collected from tributaries entering Çamderesi from the west between location 9 and Ziyaret Dere, as well as from the upper part of Karacamurlu Dere (0.5 $\mathrm{km}$ west of Kaleboynu Tepe).

The cause of the moderately high anomalies along Polatciğin Dere-Çamderesi and unnamed tributary creeks to the northwest also is not obvious. In this general region, trachyte intrudes serpentinite as irregular small plugs and possibly some sills; thus, the trachyte may form a more extensive body close beneath the surface. Careful search in this area might reveal small lead-zinc deposits near serpentinite-trachyte contacts similar to those along Sallığlanın Dere. Additional sampling is recommended in the region between Köydere and Erikli Dere, especially along previously unsampled creeks.

The moderate anomalies (locs. 13, 14, and 15, pl. 1) along Kösderesi and nearby creeks about $1 \mathrm{~km}$ northwest of Yünlüce are in an area underlain by intermediate to mafic, partly welded tuff. These anomalies may reflect base-metal mineralization at the contact between this tuff and trachyte to the south. Further sampling near the trachyte contact is recommended.

Area 2.-Four samples (locs. 30-33) indicate a significant anomaly along an unnamed tributary to Sुuul Dere near the confluence of Kamısın Dere and Kale Dere. The creek flows entirely through limestone of Karapinar Dere, which here is coarsely crystalline and evidently within the contact aureole of the syenite of Avliya Dere. The presence of this anomaly suggests the possibility of hidden base-metal deposits at the syenite-limestone contact. To verify this possibility, stream sediments should be sampled within this area.

Anomaly northwest of Darll.-A single sample from a tributary of Bağderesi about $3 \mathrm{~km}$ northwest of Darll village (loc. 29, pl. 1) is moderately aromalous. The area is underlain by fractured and faulted rocks of the Inceciğin Dere sequence. Inasmuch as nearby samples all show low metal contents, this location can probably be disregarded.

Minor anomalies northwest of Sofular.-About $5 \mathrm{~km}$ northwest. of Sofular and north of Tohma Suyu (west edge of map), a cluster of minor anomalies is concentrated over rocks of the Sofular Formation, associated diabase sills, and the overlying trachyte which includes some possible small plugs. Traces of copper mineraliza- 
tion have been reported from this general area, and additional exploration may be warranted.

Recommendations.-Geochemical prospecting carried out as of 1970 has indicated the presence of base-metal anomalies in the areas discussed above. To identify the anomalous areas more precisely and to verify the existence of additional base-metal deposits, the following supplementary work is recommended.

1. Source areas of metal should be determined in drainage basins now known to be metalliferous by sampling stream sediments along creeks and tributaries above each important confluence, except where already sampled. Soil from all springs and seepages should be sampled; a useful additional test at the sample site would be the use of a $\mathrm{BaCl}_{2}-\mathrm{HCl}$ solution to determine the content of sulfate in water from springs and seepages. In areas of known mineralization, background should be determined by sampling upstream from the deposits. Duplicate samples should be taken at each location.

2. Cold-extractable $\mathrm{Pb}, \mathrm{Zn}$, and $\mathrm{Cu}$ should be promptly analyzed in a simple field laboratory to identify anomalous areas quickly and to guide subsequent sampling.

3. On the basis of analytical results, soil sampling on a grid of $25-50 \mathrm{~m}$ should be considered in areas of high stream-sediment anomalies to determine further the size and extent of the anomalous area. However, such a grid should be modified where necessary to include samples from gullies and creeks where encountered.

4. Samples that have high metal content should be quantitatively analyzed, if possible by atomic-absorption or emission spectroscopy, although colorimetric analysis may be acceptable if controlled by standards.

5. Areas of high metal anomalies should be carefully searched for surface mineralization.

6. Additional reconnaissance sampling should be done as outlined above in areas adjacent to areas 1 and 2. Streams that should be sampled are tributaries to Ziyaret Dere; Doğankoyağı Dere, Kaçakboğaz Dere-Çayderesi, Kıliçkaya Dere, Killiören Dere, Erzincan Dere, Kırazlikoyak Dere, Çırlavuk Dere, and possibly others. (See pl. 1.)

7. If distinct target areas are identified, exploratory drilling may be considered. 


\section{CHROMITE MINES AND PROSPECTS}

Chromite is associated with ultramafic rocks in several places in and near the mapped area. All the depasits have been mined intermittently for years.

About $1 \mathrm{~km}$ south of Kuzuyatağ Tepe (south of the map area), chromite is in a possible shear zone that strikes approximately $\mathrm{N} .80^{\circ} \mathrm{W}$. and dips north. Chromite is disseminated in serpentinite and locally forms lenses; the main ore zone is about $1 \mathrm{~m}$ wide.

Five hundred meters south-southeast of Akpur Tepe, near the southwestern corner of K39- $\mathrm{a}_{1}$, several northeast-striking chromite lenses are exposed in a small, presently active mine $(\mathrm{Cr} 1, \mathrm{pl}$. $1)$.

On a broad ridge $1 \mathrm{~km}$ east-northeast of Körmustafalar, a vein or lens of chromite about $70 \mathrm{~cm}$ wide is exposed in a large pit $(\mathrm{Cr}$ 2 , pl. 1). The vein strikes about N. $65^{\circ} \mathrm{W}$. and has a subvertical dip.

The trend of chromite bodies subparallel to regional structural elements (bedding of the Tohma Group, faults, and alinement of silicified serpentinite north and northeast of Körmustafalar) suggests a primary structural control of the chromite emplacement.

\section{REFERENCES CITED}

Barosh, P. J., Serim, Salim, Gencel, illker, Sengün, Metin, and Ekren, Faruk, 1972, Geology of the Konakpinar-Sarlca area, Sivas Province, Turkey: U.S. Geol. Survey open-file report, $58 \mathrm{p}$.

Baykal, Fuat, and Erentöz, C., ed., 1966, Explanatory text of the 1:500,000scale map of Turkey (Sivas sheet): Maden Tetkin Arama Enst. Yayınlarindan (Turkey Mineral Research and Explor. Inst.), $116 \mathrm{p.}$

Brinkmann, Roland, 1968, Einige geologische Leitlinien von Anatolien: Geologica et Palaeontologica, v. 2, p. 111-119.

Cleaves, E. T., Fisher, D. W., and Bricker, O. P., 1974, Chemical weathering of serpentinite in the eastern Piedmont of Maryland: Geol. Soc. America Bull., v. 85 , no. 3 , p. $437-444$.

Coleman, R. G., 1971, Plate tectonic emplacement of upper mantle periodotites along continental edges: Jour Geophys. Research, v. 76. no. 5, p. $1212-1222$.

Cox, J. S., Jr., 1912, The iron-ore deposits of the Moa district, Oriente Province, Cuba: Am. Inst. Mining Engineers Trans., v. 42, p. 73-90.

Deer, W. A., Howie, R. A., and Zussman, J. 1963, Rock-forming minerals, v. 4, Framework silicates: London, Longmans, Green and Co., $435 \mathrm{p}$.

Dewey, J. F., and Bird, J. M., 1971, Origin and emplacement of the ophiolite suite: Appalachian ophiolites in Newfoundland: Jour. Geophys. Research, v. 76 , no. 14 , p. 3179-3206.

Garrels, R. M., and Christ, C. L., 1965, Solutions, minerals, and equilibria: New York, Harper and Row, $450 \mathrm{p}$. 
İzdar, K. E., 1963, Geologischer Bau, Magmatismus und Lagerstätten der östlichen Hekimhan-Hasançelebi Zone (Ostanatolien): Maden Tetkik Arama Enst. Yayınlarından (Turkey Mineral Research and Explor. Inst.), no. $112,72 \mathrm{p}$.

Jacobson, H. S., and Boğaz, Resat, 1972, Geology of the Karakuz iron mine and vicinity, Hekimhan district, Turkey: U.S. Geol. Survey open-file report, $20 \mathrm{p}$.

Jacobson, H. S., Kendiroğlu, Zeki, Özdemir, Celil, Boğaz, Resat, Önder, Osman, and Gürel, Nafis, 1972, Geology and mineral deposits of the Hekimhan-Hasançelebi iron district, Turkey: U.S. Geol. Survey open-file report, $39 \mathrm{p}$.

Kaaden, Gerrit van der, 1959, Age relations of magmatic activity and of metamorphic processes in the northwestern part of Anatolia-Turkey: Maden Tetkik Arama Enst. (Turkey Mineral Research and Explor. Inst.) Bull. 52 (foreign ed.), p. 15-33.

Ketin, I., 1959, The orogenic evolution of Turkey: Maden Tetkik Arama Enst. (Turkey Mineral Research and Explor. Inst.) Bull 53, (foreign ed.) p. 82-88.

1966, Tectonic units of Anatolia (Asia Minor): Maden Tetkik Arama Enst. (Turkey Mineral Research and Explor. Inst.) Bull 66 (foreign ed.) p. 23-34.

Krumbein, W. C., and Garrels, R. M., 1952, Origin and classification of chemical sediments in terms of $\mathrm{pH}$ and oxidation-reduction potentials: Jour. Geology, v. 60 , no. 1, p. 1-33.

Leith, C. K., and Mead, W. J., 1912, Origin of the iron ores of central and northeastern Cuba: Am. Inst. Mining Engineers Trans., v. 42, p. 90-102.

1916, Additional data on origin of lateritic iron ores of eastern Cuba: Am. Inst. Mining Engineers Trans., v. 53, p. 75-78.

Leo, G. W., Marvin, R. F., and Mehnert, H. H., 1974, Geologic framework of the Kuluncak-Sofular area, east-central Turkey, and K-Ar ages of igneous rocks: Geol. Soc. America Bull., v. 85, no. 11, p. 1785-1788.

McKenzie, D. P., 1970, Plate tectonics of the Mediterranean region: Nature, v. 226 , no. 5242 , p. $239-243$.

Manson, Vincent, 1967, Geochemistry of basaltic rocks-Major elements, in Hess, H. H., and Poldervaart, A. eds., Basalts-The Poldervaart treatise on rocks of basaltic composition: New York and London, Interscience, p. 215-269.

Nebert, K., 1959a, Beobachtungen über die Serpentinisierung ultrabasischer und basischer Gesteinsmassen: Maden Tetkik Arama Enst. (Turkey Mineral Research and Explor. Inst.) Bull. 52 (foreign ed.), p. 45-47. 1959b, Die Kieselbildungen des simischen Magmatismus in Anatolien: Maden Tetkik Arama Enst. (Turkey Mineral Research and Explor. Inst.) Bull., 53 (foreign ed.), p. 1-20.

Nockolds, S. R., 1954, Average chemical compositions of some igneous rocks: Geol. Soc. America Bull., v. 65, no. 10, p. 1007-1032.

Penrose Field Conference participants, 1972, Ophiolites: Geotimes, v. 17, no. 12, p. 24-25.

Petraschek, W. E., 1958, Zur Geologie der chromführenden Ophiolite der Osttürkei: Maden Tetkik Arama Enst. (Turkey Mineral Research and Explor. Inst.) Bull. 50 (foreign ed.) p. 1-14. 
Pressler, J. W., and Akar, Ali, 1971, Beneficiation studies on the Hasan Çelebi magnetite deposits, Turkey: U.S. Geol. Survey open-file report, $84 \mathrm{p}$.

Rigo de Righi, M., and Cortesini, A., 1964, Gravity tectonics in foothills structure belt of southeast Turkey: Am. Assoc. Petroleum Geologists Bull., v. 48, no. 12, p. 1911-1937.

Spencer, A. C., 1908, Three deposits of iron ore in Cuba: U.S. Geol. Survey Bull. 340 , p. $318-328$.

1912, Occurrence, origin and character of the surficial iron ores of Camaguey and Oriente Provinces, Cuba: Am. Inst. Mining Engineers Trans., v. 42 , p. $103-109$.

Thayer, T. P., 1960, Some critical differences between alpine-type and stratiform peridotite-gabbro complexes: Internat. Geol. Cong., 21st, Copenhagen, 1960, Rept., pt. 13, p. 247-259.

1967, Chemical and structural relations of ultramafic and feldspathic rocks in alpine intrusive complexes, in Wyllie, P. J., ed., Ultramafic and related rocks: New York, John Wiley and Sons, p. 222-239.

1972, Gabbro and epidiorite versus granulite and amphibolite: a problem of the ophiolite assemblage: Caribbean Geol. Conf., 6th, Isla de Margarita, Ven€zuela, 1971, Trans., p. 315--320.

Thayer, T. P., and Himmelberg, G. R., 1968, Rock succession in the alpinetype mafic complex at Canyon Mountain, Oregon: Internat. Geol. Cong., 23rd, Prague, 1968, Proc. Sec. 1, v. 1, p. 175-186.

Thornton, C. P., and Tuttle, O. F., 1960, Chemistry of igneous rocks-[Pt.] 1, Differentiation index: Am. Jour. Sci., v. 258, no. 9, p. 664-684.

Turekian, K. K., and Wedepohl, K. H., 1961, Distribution of the elements in some major units of the earth's crust: Geol. Soc. America Bull., v. 72, no. 2, p. 175-192.

Ward, F. N., Lakin, H. W., Canney, F. C., and others, 1963, Analytical methods used in geochemical exploration by the U.S. Geological Survey: U.S. Geol. Survey Bull. 1152, 100 p.

Wedepohl, K. H., 1953, Untersuchungen zur Geochemie des Zinks: Geochim. et Cosmochim. Acta, v. 3, no. 2-3, p. 93-142.

1956, Untersuchungen zur Geochemie des Bleis: Geochim. et Cosmochim. Acta, v. 10 , no. 1-2, p. 69-148.

Wijkerslooth, Paul de, 1941a, Einige neue Daten über die Genese und das Alter der Eisenerzvorkommen von Divrik (Vilâyet Sivas, Türkei) : Maden Tetkik Arama Enst. (Turkey Mineral Research and Explor. Inst.) Bull. 3/24, p. 301-319 (Turkish and German).

-1941b, Einiges über den Magmatismus des jüngeren Palaeozoikums (des Varistikums) im Raume West-Zentral-Anatoliens: Maden Tetkik Arama Enst. (Turkey Mineral Research and Explor. Inst.) Bull. 4/25, p. 536-549 (Turkish and German).

1942, Die Chromerzprovinzen der Türkei und des Balkans und ihr Verhalten zur Grosstektonik dieser Länder: Maden Tetkik Arama Enst. (Turkey Mineral Research and Explor. Inst.) Bull. 1/26, p. 35-75 (Turkish and German). 


\section{UNPUBLISHED REPORTS}

Ayan, Taner, 1964, Alvar (Darende)-Kiziliniş (Kangal)-Dürmepinar

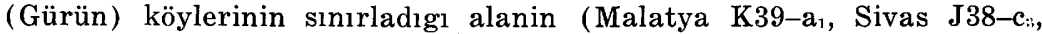
Elbistan K39-b.z paftaları) jeologisi ve petrol imkanları: unpub. rept., on file with MTA, Ankara, Turkey (map dated 1969).

Blumenthal, M., 1937, Die Hauptzüge des Baues, der Schichtfolge und der Erzführung im Gebiet von Hasan Celebi-Hekimhan (Vilayet Malatya) ; erster vorläufiger Feldbericht: unpub. rept. no. 480, on file with MTA, Ankara, Turkey.

Ilker, Sitki, 1964, Darende (Malatya) bölgesinde Malatya K39-a: ve K39-a: paftalarında detay petrol etüdü: unpub. rept., on file with MTA, Ankara, Turkey (map dated 1969).

İzdar, K. E., 1962, Studien über die Geologie und den Mineralinhalt der Umgebung von Kuluncak (vil. Malatya) : unpub. rept., on file with MTA, Ankara, Turkey.

Kovenko, V., 1939, Note sur le visite de quelques gites peu importants de la region de Karakuztepe-Alvarköy (Hasancelebi) : unpub. rept. no 815, on file with MTA, Ankara, Turkey.

Müller, H., 1937, Eisenerzvorkommen westlich und östlich von Hasan Çelebi bei Deveci, Karagöztepe u. Çaltepe: unpub. rept. no. 478 , on file with MTA, Ankara, Turkey. 

